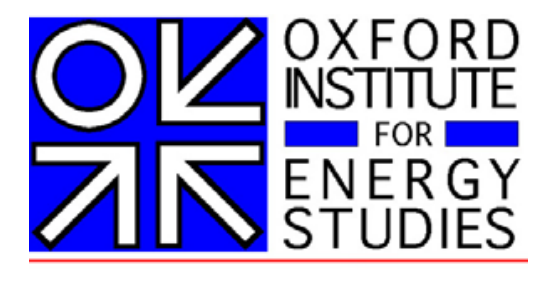

\title{
The Russo-Ukrainian gas dispute of
}

\section{January 2009: a comprehensive assessment}

Simon Pirani, Jonathan Stern and Katja Yafimava,

Oxford Institute for Energy Studies

February 2009

NG 27 
The contents of this paper are the author's sole responsibility. They do not necessarily represent the views of the Oxford Institute for Energy Studies or any of its members.

Copyright (C) 2008

Oxford Institute for Energy Studies

(Registered Charity, No. 286084)

This publication may be reproduced in part for educational or non-profit purposes without special permission from the copyright holder, provided acknowledgment of the source is made. No use of this publication may be made for resale or for any other commercial purpose whatsoever without prior permission in writing from the Oxford Institute for Energy Studies.

ISBN

978-1-901795-85-1 


\section{TABLE OF CONTENTS}

Introduction .4

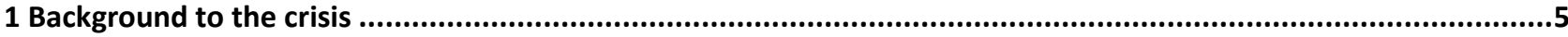

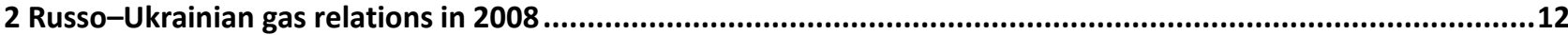

3 The Crisis of January 2009: suspension of supplies to Ukraine and Europe....................................................19

4 The resolution of the Commercial Dispute: the $\mathbf{1 0}$ year supply and transit contracts ........................................26

5 The Position of Gazprom and the Russian Government ..........................................................................31

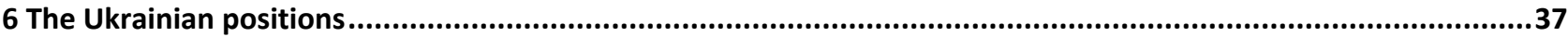

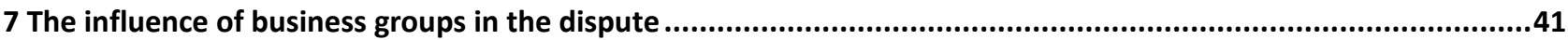

8 Major Points of Dispute between Russia and Ukraine: the 2002 transit contract ............................................43

9 The role of the European Union, Energy Charter Secretariat, and Member States ..............................................46

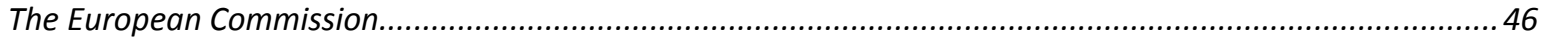

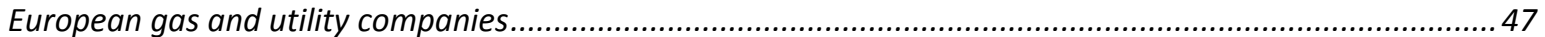

The ECT, the Energy Charter Secretariat and the consequences for gas transit.........................................49

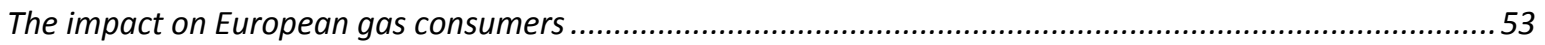

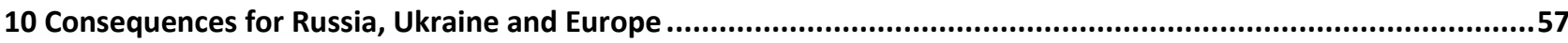

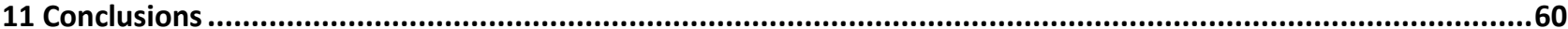

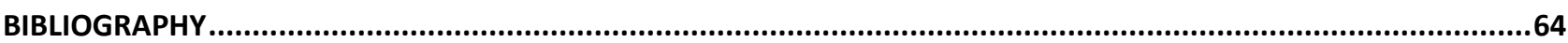

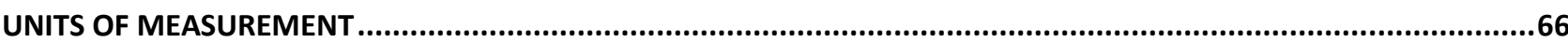

\section{Tables}

Table 1. The Russo-Ukrainian gas trade: an outline

Table 2. Illustrative European border prices, transit charges, Ukrainian netback and actual import prices in dollars per thousand cubic metres $(\$ / \mathrm{mcm})$

Table 3. Supply of Russian natural gas to Ukraine and transit for the period 1-6 January 2009,

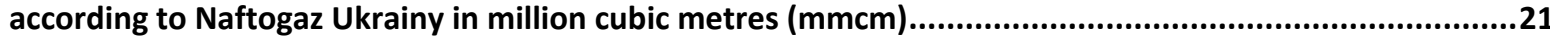

Table 4. The Position of European Countries Affected by Interruption of Russian Supply.......................................54

Illustrative boxes

The Russia-Ukraine Crisis of 1-22 January 2009: major milestones. .19

The Issue of 'Technical' (Fuel) Gas 


\section{Introduction}

The gas dispute between Russia and Ukraine in January 2009 was by far the most serious of its kind. The two sides failed to agree a price for Russian gas supply to Ukraine and a tariff for the transit of Russian gas to Europe before previous agreements expired on 31 December 2008. Russian exports to Ukraine were cut off on 1 January. Exports to 16 EU member states and Moldova were drastically reduced on 6 January and cut completely from 7 January. Deliveries to both Ukraine and other European countries restarted on 20 January following the signing of two new ten year contracts. The most seriously affected countries in the Balkans experienced a humanitarian emergency, with parts of the populations unable to heat their homes. Significant economic problems, but not of a humanitarian kind, were also caused in Hungary and Slovakia.

The crisis has far-reaching consequences. Russia's reputation as a supplier to Europe and Ukraine's reputation as a transit country, are seriously damaged. European consumers' efforts to diversify away from Russian gas, which have previously been discussed, but hardly acted on, may be expected to intensify. Projects that diversify transit away from Ukraine, such as the North Stream and South Stream pipelines, are likely to be prioritized. Further restructuring of the Ukrainian gas sector may also be expected.

This paper outlines the background to, and immediate causes and course of, the crisis. It offers an interpretation of the two sides' willingness to allow the dispute to damage their relationship with European consumers. It discusses the role of political and economic factors in the crisis, and surveys the likely consequences of the dispute. Because of the pace of these events, readers should bear in mind that it only contains information available up to 10 February 2009. 


\section{Background to the crisis ${ }^{1}$}

Ukraine is the largest single importer of Russian gas: it has been importing 47-57 bcm/year in recent years, while producing 19-21 bcm/year of its own. Ukraine is also the main corridor for Russian gas exports to Europe, accounting for about 80 per cent of transit volumes; the remainder is transported through Belarus. Estimated volumes and values are given in Table 1.

The relationship began in Soviet times, when infrastructure for Ukrainian industry and associated urban development was geared to gas as the main energy source. In the 1960s this came mainly from Ukraine's own onshore fields, but these went into decline in the 1970s, and by the time the Soviet Union broke up in 1991, Ukraine was heavily dependent on gas from the western Siberian fields. Russia was almost completely dependent on Ukraine for gas transit to Europe, the pipelines having been built on the assumption that the two countries would continue to collaborate under the Soviet umbrella.

The post-Soviet economic slump in both Russia and Ukraine during 1991-97 heightened this mutual dependence. For Russia, European gas sales were a crucial source of reliable revenue in hard times; Ukraine (along with other CIS importers) struggled to pay for gas but had no way of replacing it as a fuel source. A cycle of problems between Russia and Ukraine persisted through the 1990s: large-scale deliveries to Ukraine of gas at prices which probably did not even cover costs of delivery; accumulation of Ukrainian debts to Russia, linked to domestic non-payment; theft of gas from the transit system; and Russian pressure on Ukraine to exchange equity in the transit network and storage facilities for gas debts. The resulting disputes led Russia to cut off supplies to Ukraine on several occasions during the 1990 s. $^{2}$

\footnotetext{
${ }^{1}$ More detailed accounts of the Russo-Ukrainian gas relationship appear in our other publications. Available from the OIES website: Stern, Jonathan, (2006), The Russian-Ukrainian Gas Crisis of 2006, (Oxford, OIES, January 2006), and Pirani, Simon, (2007), Ukraine's Gas Sector (Oxford, OIES, 2007). Forthcoming in February: Pirani, Simon (ed.), (2009), Russian and CIS Gas Markets and Their Impact on Europe (Oxford, Oxford University Press, 2009). See also: Stern, Jonathan (2005), The Future of Russian Gas and Gazprom (Oxford, Oxford University Press: 2005) and Yafimava, Katja and Jonathan Stern, (2007) The 2007 RussiaBelarus Gas Agreement, Oxford Energy Comment (Oxford, OIES, January 2007); Yafimava, Katja, (2007) Post-Soviet Russian-Belarussian Relationships: the Role of Gas Transit Pipelines, Ibidem-Verlag, Stuttgart: 2007.

${ }^{2}$ For details and similar problems in relation to gas prices and debts experienced in Russia itself during this period, see Stern (2005).
} 
Table 1. Ukraine's gas trade and transit: an outline

\begin{tabular}{|c|c|c|c|c|c|c|c|}
\hline & 2003 & 2004 & 2005 & 2006 & 2007 & 2008 & $\begin{array}{l}\mathbf{2 0 0 9} \\
\text { projected }\end{array}$ \\
\hline \multicolumn{8}{|l|}{ Ukraine gas balance } \\
\hline $\begin{array}{l}\text { Ukraine, } \\
\text { consumption }\end{array}$ & 68.7 & 68.1 & 68.9 & 65.9 & 62.8 & 59.3 & 58 \\
\hline $\begin{array}{l}\text { Ukraine, technical } \\
\text { requirements }\end{array}$ & 7.6 & 7.6 & 7.4 & 8.1 & 7.0 & 7.0 & 7.0 \\
\hline $\begin{array}{l}\text { Ukraine imports } \\
\text { (presumed) }\end{array}$ & 56.9 & 55.4 & 55.8 & 53.3 & 49.1 & $54.5^{*}$ & $40^{*}$ \\
\hline Ukraine production & 19.4 & 20.3 & 20.5 & 20.7 & 20.7 & 20 & 20 \\
\hline Import price $(\$ / \mathrm{mcm})$ & $\$ 50$ & $\$ 50$ & $\$ 44-80$ & $\$ 95$ & $\$ 130$ & $\$ 179.5$ & $\$ 175-\$ 360$ \\
\hline $\begin{array}{l}\text { Total value of } \\
\text { imports, \$ bn } \\
\text { estimates }\end{array}$ & \$2.84bn & \$2.77bn & $\$ 3.2 \mathrm{bn}$ & $\$ 5.06 \mathrm{bn}$ & \$6.38bn & $\$ 8.44 \mathrm{bn}$ & $\$ 7.0-14.4 \mathrm{bn}^{* * *}$ \\
\hline \multicolumn{8}{|l|}{ Transit } \\
\hline \multicolumn{8}{|l|}{$\begin{array}{l}\text { Volumes transported, } \\
\text { bcm/year }\end{array}$} \\
\hline To Europe & 112.4 & 120.3 & 121.5 & 113.8 & 112.1 & 116.9 & 117 \\
\hline To the CIS $^{* *}$ & 16.8 & 16.8 & 14.9 & 14.7 & 3.1 & 2.7 & 3 \\
\hline $\begin{array}{l}\text { Cost of transit } \\
\$ / 100 \mathrm{~km} / \mathrm{mcm}\end{array}$ & (barter) & (barter) & $\$ 1.09$ & $\$ 1.60$ & $\$ 1.60$ & $\$ 1.70$ & $\$ 1.70$ \\
\hline $\begin{array}{l}\text { Value of transit services, } \\
\text { \$ bn, estimates }\end{array}$ & \$1.48bn & $(\mathrm{n} / \mathrm{a})$ & $\$ 1.5 b n$ & $\$ 2.2 \mathrm{bn}$ & $\$ 2.1 \mathrm{bn}$ & $\$ 2.2 \mathrm{bn}$ & \$2.35bn \\
\hline
\end{tabular}

* In 2008, Ukrainian imports plus production were higher than consumption plus technical requirements, presumably because additional gas was put into storage. In 2009, the import figure includes the amount Ukraine is contracted to buy from Russia. Its gas balance will presumably be supplemented from additional amounts in storage that it has reportedly bought from Rosukrenergo

** These are volumes transited to Moldova, and via eastern Ukraine to southern Russia. The latter volumes were sharply reduced in 2007 due to new internal Russian pipelines being commissioned.

Source: Volumes 2003-08, Energobiznes, based on fuel and energy ministry statistics; volumes 2009, as stated in contracts; prices, from public sources.

***these are the values which would result from importing $40 \mathrm{bcm}$ at prices of $\$ 175$ and $\$ 360 / \mathrm{mcm}$ respectively. The lower the volume of gas Ukraine will actually import and the later in the year it imports (assuming oil prices do not increase substantially), the lower will be the actual figure. With favourable assumptions, it could be similar to the 2008 value. 
In the late 1990s, Gazprom and the Russian government adopted two significant tactics to manage the Ukrainian trade. First, it encouraged Turkmenistan, the second-largest CIS producer, to sell gas to Ukraine, freeing up Russian volumes for Europe. Second, it used a series of intermediary trading companies (Itera from 1998, Eural Trans Gas from 2003, Rosukrenergo (RUE) from 2005) to transport, and sometimes to supply, the gas to Ukraine. RUE, which is owned 50 per cent by Gazprom (formerly by Gazprombank), 45 per cent by the Ukrainian businessman Dmitry Firtash and 5 per cent by Ivan Fursin, continued as shipper of gas to Ukraine until the end of 2008. ${ }^{3}$ The use of intermediaries was long criticized in European government circles and by corporate governance bodies (where there was concern about their opacity), and by various Ukrainian politicians (who objected to the excessive profits and corporate power bestowed on the intermediaries' owners). ${ }^{4}$

The economic recovery of Russia and Ukraine in the 2000s made possible some improvement in this chaotic relationship and raised the prospect that post-Soviet politicized horse-trading could be superceded by commercial relationships. But with both Russia and Ukraine integrating into world markets, serious problems now arose with respect to gas import prices. From 2002, as world oil prices rose steadily, so did European gas prices, which are tied to prices of (mainly) gasoil and fuel oil. From 2004, the differential between European prices and those charged to CIS countries widened sharply and Gazprom called for CIS prices be raised to the level of European netback (i.e. European border prices minus transportation charges). As a result of the 2006 crisis, Gazprom pursued this demand still more vigorously. The Russian government's decision in November 2006 to create equivalence between domestic gas prices with those in Europe by 2011 gave impetus to this principle. ${ }^{5}$ On the other hand government influence was largely responsible for the principle being applied unevenly: countries that agreed to share ownership of their pipeline systems with Russia (e.g. Belarus and Armenia) were able to negotiate much longer timetables for import price increases, while Gazprom was given leeway to raise prices more rapidly in countries whose governments sought to distance themselves from Moscow politically (in particular Georgia and Ukraine).

\footnotetext{
${ }^{3}$ For the history of this relationship see Pirani (2007).

${ }^{4}$ Global Witness, 'It's a Gas - Funny Business in Turkmen-Ukraine Gas Trade', April 2006. Available at: www.globalwitness.org/media_library_detail.php/479/en/its_a_gas._funny_business_in_the_turkmen_ukraine_ g

${ }^{5}$ For details see Stern in Pirani (2009). Note that this only applied to non-residential prices and that because of transit tariffs and export taxes, Russian prices can be less than half of European levels and still be considered 'equivalent'.
} 
In Ukraine's case, a dispute erupted in January 2006 that concerned both prices (Gazprom's offer and Ukraine’s bid were further apart than ever), and the terms on which gas would be imported (i.e. how the Turkmen-Russian-Ukrainian relationship would be managed and what role the intermediaries would play). That dispute is the only occasion prior to January 2009 when Russian supplies to a significant number of European countries were significantly disrupted. Russia cut off Ukrainian import volumes for three days, Ukraine diverted volumes destined for Europe, and supplies to some central European countries fell briefly. However, supplies were never completely cut off, and in most countries the effects amounted to little more than minor inconvenience. ${ }^{6}$ The agreement that ended the dispute made little progress towards European netback prices, but it strengthened Russia's position in four other respects:

1. It ended the practice of barter deals (imported gas for transit services) that had blighted Russo-Ukrainian gas trade since 1991, and thereby paved the way for greater transparency and the use of market mechanisms. Transit fees were henceforth to be paid for in cash; they were lower than those in central Europe, as were import prices, while storage tariffs paid by RUE were a fraction of comparable rates elsewhere.

2. The status of transit and supply contracts changed, although how they changed is open to different interpretations. Gazprom's version of events is that supply and transit were separated, and a long term transit contract, which was intended to make supplies to Europe independent of Russo-Ukrainian gas trade, was signed. Two alternative views of the contractual situation are that:

- there was a separate transit contract from 2002, but what was missing after 2006 was an intergovernmental agreement that bound the two contracts together. In addition, the transit contract was between Gazprom and Naftogaz, whereas the 2006 supply contracts were between RUE (seller) and Naftogaz and Ukrgaz-Energo (buyers).

- there never was any other separate supply contract, and that the so called 'separation of transit and supply' essentially amounted to the conclusion of the 2006 January crisis one page agreement. This effectively annulled

\footnotetext{
${ }^{6}$ See footnote 9 below, Stern (2006).
} 
supply provisions of the 2002 contract, whereas the transit provisions of that contract remained valid.

3. The agreement confirmed that Ukraine would no longer negotiate directly with Turkmenistan. All Turkmen export volumes were now bought by Gazprom Export at the Turkmen border and, apart from small amounts used in Russia, resold to RUE, which would ship and supply Ukraine's imports and sell 7-10 bcm/year in central Europe. Prices were based not on a European netback calculation, but on a 'net forward' from Turkmen export prices, which reached an average of $\$ 140 / \mathrm{mcm}$ in $2008 .^{7}$

4. A wholesale trader, Ukrgaz-Energo, a joint venture between RUE and the Ukrainian state-owned oil and gas company Naftogaz Ukrainy, was given a dominant position in the Ukrainian domestic gas market.

Much as Gazprom would have liked to impose European netback prices on Ukraine at this stage, it was unable to. It was not just that this would have imposed a burden on the Ukrainian economy that its government was desperate to avoid; it was also that that government, and Naftogaz Ukrainy, had shown they were prepared to use their nearmonopoly of Russian transit to Europe as the ultimate bargaining chip. During the dispute, when Russia withheld volumes destined for Ukraine from the network, Ukraine simply withdrew gas destined for Europe. ${ }^{8}$ This balance of forces, and the sheer rapidity of European price increases, meant that Gazprom failed to narrow the differential between European and Ukrainian prices, shown in Table 2.

\footnotetext{
${ }^{7}$ Prices for Turkmen gas - which is the majority of Central Asian gas bought by Gazprom - and for Uzbek gas tend to be the same, and were $\$ 130 / \mathrm{mcm}$ in the first half of 2008 and $\$ 150 / \mathrm{mcm}$ in the second half; Kazakh export price was $\$ 180 / \mathrm{mcm}$. For details of Central Asian gas exports see the chapters on Turkmenistan, and those by Zhukov and Yenikeyeff in Pirani (2009).

${ }^{8}$ Ukrainian officials have publicly denied that any European gas was diverted to their customers during the 2006 dispute, but given the loss of gas in Europe, no other explanation is possible, unless Gazprom failed to deliver those volumes.
} 
Table 2. Illustrative European border prices, Transit Charges, Ukrainian Netback and Actual Import Prices in Dollars per Thousand Cubic Metres (\$/mcm)*

\begin{tabular}{|l|l|l|l|l|l|}
\hline & $\begin{array}{l}\text { \$/mcm } \\
\text { European } \\
\text { border (est) }\end{array}$ & $\begin{array}{l}\text { Transit } \\
(\mathbf{e s t})\end{array}$ & $\begin{array}{l}\text { Netback } \\
(\text { est.) }\end{array}$ & $\begin{array}{l}\text { Actual } \\
\text { import prices }\end{array}$ & Differential \\
\hline $\mathbf{2 0 0 4}$ & 143.05 & 27.00 & 116.05 & 50 & 66.05 \\
\hline $\mathbf{2 0 0 5}$ & 189.31 & 31.58 & 157.73 & $50-80$ & $77.73-107.73$ \\
\hline $\mathbf{2 0 0 6}$ & 246.51 & 36.53 & 209.98 & 95 & 114.98 \\
\hline $\mathbf{2 0 0 7}$ & 254.48 & 38.35 & 216.13 & 130 & 86.13 \\
\hline $\mathbf{2 0 0 8}$ & 368.32 & 41.13 & 327.19 & 179.50 & 147.69 \\
\hline
\end{tabular}

*note that the only figures which we can be sure of in this table are the Ukrainian import prices. None of the other data are in the public domain. Our European price estimates for 2008 are significantly below the figure of $\$ 450$ agreed as the starting point for the 2009 price. The point the data illustrate is that even at much lower European price estimates, the differential is still substantial.

In 2006-08, Gazprom's drive to introduce European netback prices for CIS importers was given fresh impetus by a new surge in oil prices, which in 2008 took European gas prices briefly higher than $\$ 500 / \mathrm{mcm}$. In January 2007 the growing gap between CIS and European prices caused a crisis in Russo-Belarussian relations, which was resolved when Belarus agreed to sell a 50 per cent share of its transit network to Gazprom by 2010 (with the latter set to make four equal payments during 2007-2010) and to accept a three-year timetable for transition to European netback prices. ${ }^{9}$ Ukraine’s import prices for 2007 were settled without a major dispute, perhaps in part because Russia did not want to be in conflict with both the transit countries at the same time.

However, conflicts between political and business groups in Kiev - which had long been a factor in Ukraine's gas sector - now came to the fore in negotiations with Moscow. The Ukrainian government formed in September 2006, headed by Viktor Yanukovich of the Party of Regions - which has a strong electoral base in Russian-speaking eastern Ukraine - was dismissed in September 2007 and elections called. These resulted in the return of Yulia Timoshenko to the prime ministership. She immediately set out to make good her election promise to drive RUE (and its part owner Firtash) out of the gas trade; demanded direct sales by Gazprom Export to Naftogaz; and initiated the dissolution of Ukrgaz-Energo, which acted

\footnotetext{
${ }^{9}$ The gas price was set to correspond to a percentage of the price at which Gazprom exports its gas to Europe 67 per cent, 80 per cent and 90 per cent for 2009, 2009, and 2010 respectively. See Yafimava and Stern, op. cit.
} 
as a vehicle through which RUE and its owners were establishing a strong position in the Ukrainian gas market. 


\section{Russo-Ukrainian gas relations in 2008}

In late 2007, import prices for 2008 gas supplies to Ukraine were set at $\$ 179.50 / \mathrm{mcm}$, up from $\$ 130 / \mathrm{mcm}$ in 2007; all imports were to be sold by RUE to Ukrgaz-Energo at the Ukrainian border. Transit tariffs were set at $\$ 1.70$ per thousand cubic metres per hundred kilometres ( $\$ / \mathrm{mcm} / 00 \mathrm{~km}$ ), up from $\$ 1.60 / \mathrm{mcm} / 00 \mathrm{~km}$ the previous year. (Despite the fact that Gazprom treated Ukrainian supplies as if they had been purchased on the Turkmen border and physically delivered to Ukraine, the likelihood is that this did not happen and that most of the gas which Ukraine imported has always been physically sourced from Russia. ${ }^{10}$ )

Timoshenko's return as prime minister put these arrangements in doubt. Ukrainian stateowned companies including Naftogaz Ukrainy voided sales contracts with Ukrgaz-Energo, and by February, Gazprom was complaining loudly that Ukrainian offtake of gas was not covered by contracts. On 12 February 2008, presidents Putin and Yushchenko agreed:

- to replace RUE, from 2009, by a trader owned jointly by Gazprom and Naftogaz Ukrainy;

- that Ukrgaz-Energo would be replaced by Naftogaz as the importer of central Asian gas,

- that a wholesaler, wholly owned by Gazprom, would be licensed to work on the Ukrainian market. A series of details were to be worked out at corporate level.

When negotiations faltered on 3 March, Gazprom reduced the pressure in transit pipelines, as it had done in January 2006. Naftogaz responded by warning that if Russia could not guarantee supplies to Ukraine, Naftogaz could not guarantee transit of volumes to Europe. Agreements signed before pressure in the pipes was restored weakened Firtash's position in the domestic market, but strengthened Gazprom’s: a 100 per cent Gazprom-owned Ukrainian trader, Gazprom-Sbyt, was guaranteed a $7.5 \mathrm{bcm} /$ year share of the lucrative industrial market. Moreover, Kiev committed itself to negotiate on the basis of European netback

\footnotetext{
${ }^{10}$ Because gas is a homogenous product, it is impossible to be certain where any gas consumed in any particular location originated. However, we shall see below that this methodology of 'netting forward' from Central Asia disappeared in the 2009 contract.
} 
prices, and the three central Asian exporters announced in Moscow that they also would, from 2009, base sales prices to Gazprom on European netback. ${ }^{11}$

Some important elements for future cooperation in the gas sphere - moving towards European netback prices, dispensing with the intermediaries, agreeing on direct Gazprom participation in the Ukrainian market - were set out in the February agreement. In October 2008 they were set out in considerably more detail, in a memorandum between the countries' governments signed by prime ministers Timoshenko and Putin ${ }^{12}$. The memorandum included the following provisions:

-- From 1 January 2009, Naftogaz would buy gas directly from Gazprom, and would be the sole importer to Ukraine. (This ruled out a return of Ukrgaz-Energo.) This arrangement would be dependent on clearance of Ukrainian debts, timely payment for future deliveries, and access to Ukrainian customers for Gazprom subsidiaries (implying a continuation or expansion of the 2008 arrangement, whereby Gazprom Sbyt sells 7.5 bcm to Ukrainian industrial customers);

-- Import prices and transit tariffs to be raised step by step to 'market, economically based and mutually agreed levels’ within three years;

-- The 'necessity for uninterrupted transit of gas across Ukrainian territory on a long-term basis’ was recognized;

-- Gazprom and Naftogaz would jointly export some gas to Europe, including incremental volumes from storage. (This gave Ukraine the prospect of exposure to the European market from which it had effectively been excluded by the 2006 agreement.)

Within three weeks, on 24 October, an agreement, On the Principles of Long-term Cooperation in the Gas Sector, was signed by the chief executives of Gazprom and Naftogaz

\footnotetext{
11 'One step forward, two steps back for Timoshenko', Gas Matters, March 2008, p. 1, 'Winners and losers in the March 2008 Russo-Ukrainian "gas war” ', Gas Matters, April 2008, p. 14.

${ }^{12}$ Whereas earlier in the year Timoshenko had struck an antagonistic stance, and Yushchenko acted as peacemaker, with Moscow.
} 
- Aleksei Miller and Oleg Dubyna. ${ }^{13}$ This built on the Putin-Timoshenko memorandum, repeating the above points, and also specifying:

-- That Naftogaz debts owed to RUE would be converted into a debt to Gazprom;

-- That a long-term contract, providing for the three-year transition to 'market, economically based and mutually agreed' gas prices was to be signed by 1 November 2008;

-- That Naftogaz's guarantee of 'reliable and uninterrupted transit' would apply to volumes of at least $120 \mathrm{bcm} /$ year;

-- That a two-month supply contract would be concluded by 30 October 2008 for Central Asian gas to be supplied by Gazprom to Naftogaz at $\$ 179.50 / \mathrm{mcm}$ (implying that the intermediary RUE and the trader Ukrgaz-Energo would be removed from the import business immediately);

-- That the January 2006 agreements would be annulled as soon as the conditions of this agreement were met.

It is clear from the text of this agreement that there had been some renegotiation on the issue of transit fees. The Putin-Timoshenko memorandum referred to transit fees being moved to 'market, economically-based' levels along with import prices, but the Miller-Dubyna agreement referred to transit fees retaining their 2008 level $(\$ 1.70 / \mathrm{mcm} / 00 \mathrm{~km})$, and envisaged a long-term transit contract with fees 'correlated, with a declining coefficient' to the price of $6.4 \mathrm{bcm}$ of 'technical' (fuel) gas used by the pipeline system during transit. ${ }^{14}$

Both the prime ministers' memorandum and the corporate agreement refer to the possibility of joint Gazprom-Naftogaz sales in Europe, but neither document says anything about RUE's sales of central Asian gas in central Europe. RUE part-owner Dmitry Firtash stated in January 2009 that the company had contracts to supply $7 \mathrm{bcm}$ of gas to Poland, Hungary, and

\footnotetext{
${ }^{13}$ A copy of the document was reproduced in Alla Eremenko, 'Novy god pod “Gazpromom” otmeniaetsia?', Zerkalo Nedeli, 18 October 2008, www.zn.ua/1000/1550/64418/. Oleg Dubyna, CEO of Naftogaz, was elsewhere quoted as refusing to confirm that the copy was genuine, but there seems little reason to doubt that it was.

${ }^{14}$ For a discussion of ‘technical gas' see Box 2.
} 
Romania in 2009, which it would fulfil. The future of this part of RUE's business is unclear at the time of writing. ${ }^{15}$

Why did the two parties fail to reach agreement on 2009 gas prices and transit tariffs? Or, put another way: having made so much progress in October, and having set out a basis for much improved relationships in the gas sphere, why did they fail to implement what they had agreed?

Relying primarily on the mass of publicly available material, we would answer as follows. ${ }^{16}$ Certainly a big part of the problem was Naftogaz's failure to clear debts for gas delivered. Large amounts remained outstanding on and after 30 October, the deadline by which Miller and Dubyna had agreed to sign a long-term supply contract. During November, a \$268.7 million payment was made, out of \$550 million owing for September. On 2 December, Naftogaz acknowledged that it owed around \$1 billion, and that it was having difficulty making payments on time due to unexpected losses during 2008 (2.8 million hryvna of unpaid accounts by district heating companies in 2007-8, 1.6 million hryvna for Value Added Tax not paid on imports in the first quarter of 2006, and 600 million hryvna due to the fall in the value of the hryvna against the US dollar). In mid December Gazprom stated that a debt of \$2.195 billion had accumulated; in response, Naftogaz made a payment of \$800 million and promised that a further $\$ 200$ million would soon be paid. ${ }^{17}$

From this point the two sides engaged in an increasingly acrimonious public dispute. Gazprom proposed to make an upfront payment for transit at the 2008 rate $(\$ 1.70 / \mathrm{mcm} / 100 \mathrm{~km})$, in order to provide funds for the debt to be cleared, but this offer was rejected by Naftogaz. ${ }^{18}$ On 19 December Gazprom said:

(a) Ukraine had stated that no new payments would be made until the end of 2008,

(b) in this case - and if no other ways of settlement other than cash payment will be agreed - no supply contract could be signed for 2009 .

\footnotetext{
${ }^{15}$ Reznik, Irina, 'RUE uzhe kontroliruet 75 per cent prodazh gaza na Ukraine’, Vedomosti, 11 January 2009.

${ }^{16}$ In dealing with the progress of the dispute, we have relied on huge quantities of material from the websites of governments, gas companies, newspapers, and news agencies, as well as on sources within the Russian, Ukrainian and European gas industries. We have concentrated on providing references for statements that are disputed, or controversial, or for information not widely available, rather than burdening the text with sources for widely available or uncontroversial information.

${ }^{17}$ Naftogaz press release, 2 December 2008; ‘Ukraina ne rasschitalas’ v polnom ob”eme za postavki gaz v sentiabre', www.interfax.ru, 2 December 2008.

${ }^{18}$ Aleksandr Chernovalov, 'Poruchitel’naia istoriia', Kommersant, 17 December 2008.
} 
This version of events was vehemently denied by a Naftogaz spokesman. ${ }^{19}$ On the same day Bogdan Sokolovsky, the Ukrainian president's spokesman on international energy security, stated that Ukraine, having paid for September and October supplies, no longer owed money to Gazprom and that, although it had to pay for November supplies before the end of 2008, no payment for December supplies would be due until the end of January $2009 .^{20}$

As early as the third week of November, Gazprom CEO Miller, following a meeting with the Russian president, announced that if no agreement was reached by the end of the year, prices could rise to $\$ 400 / \mathrm{mcm}$ on 1 January 1 2009, and a few days later Prime Minister Putin added that if there was any interference with transit gas, supplies to Ukraine would be cut off. ${ }^{21}$ These warnings were repeated throughout December with the addition that disruption to European supplies could result (see the section on the position of Gazprom and the Russian government below). The European Commission made no attempt to intervene, but the Energy Charter Secretariat issued a statement on 23 December in which the Secretary General made reference to the dispute (before any gas supplies had been cut off) and recalled the principle of uninterrupted transit. ${ }^{22}$ This could be construed as a reminder to Ukraine of its obligations under the Energy Charter Treaty, which it has signed and - unlike Russia - ratified. (For details, see the section on European-based organizations below.)

Naftogaz, although in serious financial difficulties, was in a position to pay its debt. The government had amended the budget to allow for a guarantee of $\$ 2$ billion to be extended to Naftogaz, on the basis of which it could have borrowed from state banks. The Ukrainian president had also instructed the national bank to ensure that foreign exchange was made available to Naftogaz in time. The IMF’s \$16.5 billion loan to Ukraine was earmarked for other purposes, but clearly gave the state finances a substantial cushion; at the height of the debt dispute the Financial Times reported that 'the IMF says Kiev has the means to pay'. ${ }^{23}$ In the end, Naftogaz made a payment of $\$ 1.52$ billion for outstanding gas deliveries to RUE on

\footnotetext{
19 'Ukrainu snova otkluchaiut'. Available at:www.vedomosti.ru, 19 December 2008; 'O raschetakh NAK “Naftogaz Ukrainy”, , Naftogaz press release, 23 December 2008; “"Naftogaz Ukrainy” otritsaet dolgi za rossiiskii gaz’, Kommersant-Ukrainy, 23 December 2008.

20 'Predstavitel' Iushchenko: Naftogaz nichego ne dolzhen Rossii za gaz', 19 December 2008. Available at: www.vz.ru/news/2008/12/19/240483.html

${ }^{21}$ Interfax, November 20-26, 2008, p. 6 and December 4-18, p.6.

22 'Secretary General Issues Statement on Russia-Ukraine Gas Dispute', Energy Charter website. Available at: www.encharter.org/index.php?id=21\&id_article $=165 \& \mathrm{~L}=0$

${ }^{23}$ Wagstyl, Stefan and Roman Olearchyk, (2008), 'Heat rises in Russia-Ukraine gas talks', Financial Times, 16 December 2008
} 
30 December. Gazprom insisted that a further $\$ 614$ million in fines and penalties was outstanding, although on 2 January Naftogaz claimed that no further amounts were outstanding, and said it was ready to go to international arbitration to resolve this issue. ${ }^{24}$ However, in terms of reaching agreement, this was too little, too late. Furthermore, on 31 December, the chief executive of Naftogaz, Oleg Dubyna, appears to have written to Gazprom, warning that if it delivered gas for transit to Europe, Naftogaz would consider this gas to belong to an 'unidentified owner' and it could be confiscated under Ukrainian customs law. Assuming the letter was genuine - a facsimile of it was reproduced by an independent media outlet, as well as being presented to journalists by Gazprom representatives, and Dubyna at no time denied its existence ${ }^{25}$ - it amounted to little more than a threat to divert gas as Ukraine had done in 2006.

Before we come to the events of the crisis itself, unresolved questions remain about its origins. First, why did Gazprom allow Ukrainian debt to build up to even the \$1.6bn which Naftogaz acknowledged was due, let alone to the \$2.2 billion which Gazprom was claiming should be paid by the end of the year? Surely, even reasonably prudent commercial practice should have dictated that supplies to Ukraine should have been cut off much earlier, while the existing contract had at least some weeks to run. One reason could be that, following the signing of the October Putin-Timoshenko memorandum, Gazprom did not want to commit the unfriendly act of cutting off gas, because it still had hopes that a new contract could be concluded amicably. Rapid settlement of 2009 supplies, prices, and tariffs was in Gazprom’s best interest, since it would send a reassuring message to its European buyers that any repetition of the January 2006 events would be avoided. At the same time, dramatically falling oil, and hence gas, prices were already certain to translate into sharply falling Gazprom earnings in 2009, making Gazprom even keener to collect all possible revenues, including those from Ukraine. Thus Gazprom made the conclusion of a new 'transition' contract (i.e. with a step-by-step increase to European price levels) with Ukraine conditional on a full repayment of the debt.

\footnotetext{
${ }^{24}$ Gavrish, Oleg et al., (2008), 'Pravitel'stvo vypisyvaet “Naftogazu” garantiu', Kommersant, 24 December 2008; 'Iushchenko rasskazal', www.ukroil.com.ua, 24 December 2008; 'Ukraina polnost'iu rasschitalis”, press release of the Ukrainian presidential administration, 30 December 2008; 'Gazprom i Naftogaz: spornye voprosy ne resheny’, www.interfax.ru, 2 January 2009; Naftogaz press release, 2 January 2009

25 'Naftogaz i Gazprom: perepiska', Ekho Moskvy radio site, www.echo.msk.ru/blog/echomsk/563350echo.phtml, 1 January 2009
} 
Another reason for the huge build-up of debt could be that RUE - to which most of the debt was owing - had failed adequately to monitor the situation and coordinate its actions with Gazprom, but since Gazprom is a 50 per cent owner of RUE that seems implausible. In any event, quite aside from governance issues, it illustrated other problems arising from the use of an intermediary: was it RUE's responsibility to cut off Ukraine because of the high level of debt or was it Gazprom's? When Gazprom claimed that it had not received the \$1.52bn which Naftogaz paid to RUE on 30 December by the end of the year, there was some lack of clarity as to whether this was RUE's fault or a failure of the banking system to process the paperwork sufficiently quickly.

Finally, a lesson from 2006 - and from all previous crises - was that the Russia-Ukraine contract should not have been allowed to run out at the end of the year in the middle of winter. General European gas industry practice is that the gas year (and gas contracts) runs from 1 October to 30 September the following year. While weather can still be cold at the beginning of October, it is far preferable to the 31 December expiry date. Yet neither side had made any attempt to change the term of the contract. 


\section{The Crisis of January 2009: suspension of supplies to Ukraine and Europe}

\section{Box 1. The Russia-Ukraine Crisis of 1-22 January, 2009: major milestones}

- 1 January: Gazprom cuts all supplies for Ukrainian consumption, while supplies to Europe continue

- 5 January: Gazprom alleges that $65.3 \mathrm{mmcm}$ of gas has been 'stolen' during the first four days of the year; Ukraine responds that in the absence of a supply and transit contract it is entitled to take this 'technical' (fuel) gas

- 6 January: deliveries to Europe drastically reduced

- 7 January: deliveries to Europe completely cut off

- 11 January: EU monitors deployed

- 13-17 January: Gazprom cites daily attempts to resume flows ‘blocked by Ukraine’

- 14 January: letter from Naftogaz to Gazprom cites lack of a 'technical agreement' preventing resumption of flows

- 19 January: ten year supply and transit contracts signed

- 20 January: gas flows to Ukraine and Europe restart

- 22 January: gas flows to all European customers returning to normal levels

The first four days of the crisis were relatively uneventful. But in sharp contrast to 2006 when by 4 January the crisis was over and flows were returning to normal - in 2009 this was the starting point of a more serious conflict. On 4 January, Gazprom claimed Ukraine had 'stolen' 50 million cubic metres $(\mathrm{mmcm})$ in the 24 hours up to $10.00 \mathrm{am}$ on that day -25 mmcm from Gazprom's European customers and 25 mmcm from RUE’s stored gas. ${ }^{26}$ On 5 January, Gazprom claimed that during the first four days of the year Ukraine had 'stolen' $65.3 \mathrm{mmcm}$ of gas and called upon Ukraine to make this up by supplying from its own resources a corresponding volume on its western border. ${ }^{27}$ Naftogaz Ukrainy published the actual daily volumes it claimed had flowed on those days, showing a discrepancy of only

\footnotetext{
26 'Gazprom calls on Naftogaz Ukrainy to resume negotiations', Ukrainefacts, 4 January 2009.

27 'Gazprom reduces the volume of gas supply to the Ukrainian gas transportation system', Ukrainefacts, 5 January 2009. It was not clear whether the $50 \mathrm{mcm}$ was included in, or additional to, the $65.3 \mathrm{mcm}$.
} 
$52.2 \mathrm{mmcm}$ of (technical) gas used by the network over a six day period (Table 3). Ukraine further claimed that up to $23 \mathrm{mmcm} /$ day of 'technical' (fuel) gas was needed to operate the network and, in the absence of a supply and transit contract, it was entitled to take this fuel gas out of European transit volumes (Box 2). However, during 1-5 January substantial - even if incomplete - volumes of gas continued to flow to Europe.

\section{Box 2. The Issue of 'Technical' (Fuel) Gas}

Gas required to run the compressor stations is generally known in the gas industry worldwide as 'fuel gas'. General practice is that fuel gas is provided by the transportation/transit company and included in the tariff charged to the shipper i.e. there is no separate price or tariff charge for this gas. In the former Soviet Union it has customarily been referred to as 'technical' gas and we have used this label in this study. During the negotiations, the Ukrainian side periodically raised the issue of a separate (discounted) price for this gas. The issue of technical gas, which would come to play an important part in the crisis, was raised from the first day. On 1 January, Naftogaz issued a statement saying it guaranteed to fulfil all its obligations on transit, but then qualified this: it would transit Russian gas to European consumers 'exclusively in the volumes provided for in existing agreements, which result from pre-contractual negotiations'; in the absence of 'an additional agreement regarding transport', it could not: 'define the conditions for settlement for transit services', 'undertake customs declarations for the volumes of transit from importer countries' or 'guarantee synchronized operation of the gas transport systems of Ukraine, Russia, and the EU'. ${ }^{28}$ In a further statement two days later, it clarified that this meant it would take technical gas, at the rate of $23 \mathrm{mmcm}$ a day, from volumes bound for Europe. Its argument was that this was the amount specified in the last intergovernmental memorandum attached to the transit contract signed in 2002, to cover 2003-13. ${ }^{29}$ Bogdan Sokolovsky, President Yushchenko's spokesman on international energy security, confirmed this in a statement that the Ukrainian pipeline system was receiving $283 \mathrm{mmcm}$ a day, which was all being transported to Europe 'with the exception of "technical" gas'. ${ }^{30}$ Gazprom spokesman Sergei Kuprianov defined the use of technical gas from the Russian volumes as 'stealing', and announced that Gazprom would take the matter to the international arbitration court at Stockholm; on 4 January he stated in a press release that $50 \mathrm{mmcm}$ had so far been 'stolen' in this way. ${ }^{31}$

\footnotetext{
28 'NAK “Naftogaz Ukrainy” garantiruet vypolnenie vsekh obiazatel’stv', Naftogaz Ukrainy website, 1 January 2009

${ }^{29}$ 'NAK “Naftogaz Ukrainy” schitaet svoi deistviia legitimnymi', Naftogaz Ukrainy website, 3 January 2009

30 'B. Sokolovskii: Ukraina v polnom ob"eme vypolniaet svoi obiazatel'stva po tranzitu gaza', www.president.gov.ua, 3 January 2009

31 'Ukraine accused of stealing gas', BBC News website, 2 January 2009; 'Za proshlye sutki evropeiskie potrebiteli', Gazprom website, 4 January 2009
} 
Table 3. Supply of Russian Natural Gas to Ukraine and Transit for the Period 1-6 January, 2009, according to Naftogaz Ukrainy in Million Cubic Metres (mmcm)

\begin{tabular}{|l|l|l|l|}
\hline Date & Supplies from Russia & $\begin{array}{l}\text { Volumes of transit to } \\
\text { Europe and Moldova }\end{array}$ & $\begin{array}{l}\text { Difference between } \\
\text { supplies and transit } \\
\text { volumes }\end{array}$ \\
\hline $01 / 01 / 2009$ & 318.2 & 318.4 & -0.2 \\
\hline $02 / 01 / 2009$ & 300.0 & 295.2 & +4.8 \\
\hline $03 / 01 / 2009$ & 293.2 & 269.8 & +23.3 \\
\hline $04 / 01 / 2009$ & 303.1 & 269.1 & +34.0 \\
\hline $05 / 01 / 2009$ & 214.0 & 228.0 & -14.0 \\
\hline $06 / 01 / 2009$ & 59.7 & 55.4 & +4.3 \\
\hline Total & $\mathbf{1 4 8 8 . 2}$ & $\mathbf{1 4 3 5 . 9}$ & +52.2 \\
\hline
\end{tabular}

Source: NJSC Naftogaz of Ukraine is indignant at OJSC Gazprom's statements, Naftogaz

Ukrainy website, 7 January, 2009.

The night of 5 January and early hours of 6 January were possibly the key moments in this crisis as far as deliveries to Europe were concerned. On the $5^{\text {th }}$, a televised (and rather obviously staged) conversation between Prime Minister Putin and Gazprom CEO Miller rehearsed all of the Russian grievances against Ukraine and culminated in Putin agreeing with Miller's proposal to reduce the gas flows, and instructing him to inform Gazprom's European partners about the reasons for this action. ${ }^{32}$ In addition, and somewhat bizarrely, Gazprom said that the Federal Customs Service had informed it that because of the alleged theft of the $65.3 \mathrm{mmcm}$, the company was in violation of Russian customs and currency legislation, providing it with another reason to withhold these volumes. ${ }^{33}$

On 6 January, Gazprom deputy CEO Aleksandr Medvedev stated at press conferences in both London and Berlin that Ukraine had blocked three of the four transit lines 'in an

\footnotetext{
${ }^{32}$ The logic of the discussion suggests that Putin is referring to cutting off the $65.3 \mathrm{mmcm}$ which Ukraine was alleged to have stolen, rather than cutting off the entire flow of gas to Ukraine and Europe. The text of the Putin/Miller exchange can be found in: 'Predsedatel' pravitelstva Rossiskoi Federatsii V.V Putin provel rabochuiu vstrechu s predsedatelem pravleniia OAO Gazprom A.B. Millerom', www.government.ru/, 5 January 2009; 'Gazprom reduces the volume of gas supply to the Ukrainian gas transportation system', Ukrainefacts, 5 January 2009.

${ }^{33}$ This part of the text reads: 'The Federal Customs Service instructed OAO Gazprom to take immediate measures and optimize gas delivery routes and regimes for European consumers and other measures necessary to comply with customs and currency legislation of the Russian Federation. In this connection Gazprom decided to reduce the supply of gas to the gas transportation system of Ukraine by 65.3 million cubic meters, i.e. by the volume that accumulated on the territory of Ukraine from 1-4 January 2009'. 'Gazprom reduces the volumes of gas supply to the Ukrainian gas transportation system', Ukrainefacts, 5 January 2006.
} 
unprecedented and unilateral move' at 02.30; Naftogaz categorically denied this, and stated that it had that day used its own gas for technical purposes. ${ }^{34}$ President Yushchenko stated that Gazprom had sharply reduced the volumes it was putting in the system (from 262 $\mathrm{mmcm}$ /day to $73 \mathrm{mmcm}$ /day during the course of the day). ${ }^{35}$ Later that day, Gazprom spokesman Kuprianov stated that the company had on that day put only $64.7 \mathrm{mmcm}$ in to the system, and was expecting Ukraine to make up the $65.3 \mathrm{mmcm}$ needed to make $130 \mathrm{mmcm}$ of orders. It remains unclear why only $130 \mathrm{mmcm}$ were needed that day compared to the usual 280-300 mmcm, but it may have been part of a less well-articulated Russian refusal to continue deliveries in the event of (what was construed as) ongoing gas theft. ${ }^{36}$ On 7 January 2009, Gazprom CEO Aleksei Miller stated that Gazprom had stopped all deliveries into the system because Ukraine had closed it down; Naftogaz said it had closed down the system because Gazprom had stopped delivering gas at $07.44 .^{37}$

At this point, on 7 January, the second and more serious stage of the dispute began. Gas was cut off completely to countries in south-eastern Europe which are 100 per cent dependent on Russian imports, and partially to other countries, for 13 days. The Russian and Ukrainian sides blamed each other; neither displayed great urgency about moving towards agreement. It is important to underline the unprecedented nature of this situation. Supplies to Europe had never been halted since the gas transit system was built in Soviet times, and even in 2006 the shortfalls in supplies to Europe resulted not from European supplies being completely halted, but from Ukraine being cut off and diverting a proportion of European volumes for its own use.

With each side blaming the other for the stoppage, it was clear that independent oversight of gas flows would be necessary. In the days up to 10 January, a European Union initiative established the terms of reference for a monitoring mission with experts drawn from both sides of the dispute; the EU and all the major continental European gas companies to be

\footnotetext{
34 'Alexander Medvedev gave a joint press briefing after meeting with Michel Glos, German Minister of Economics’, Ukrainefacts, 6 January 2009; “OAO “Gazprom” v chetyre raza ot planovykh ob”emov sokratil postavki’, Naftogaz Ukrainy press release, 6 January 2009.

${ }^{35}$ Although this figure did not correspond exactly with the Naftogaz data in Table 3; 'Viktor Iushchenko: Ukraina ispol'zuet dlia svoikh potrebitelei iskliuchitel'no gaz sobstvennoi dobychi', www.president.gov.ua, 6 January 2009

36 'Eto nado delat’ publichno’, www.interfax.ru, 7 January 2009.

37 'Ukraine closed last transit pipeline to Europe', Ukrainefacts, 7 January 2009; 'NJSC Naftogaz of Ukraine is indignant at OJSC Gazprom’s statements’, Naftogaz Ukrainy website, 7 January 2009.
} 
deployed at key entry and exit points on the transit and storage network. ${ }^{38}$ But even then there was a last minute problem when Prime Minister Timoshenko, the final party to sign, appended a handwritten note to the effect that her signature was subject to a 'declaration', which effectively restated the Ukrainian commercial position blaming the Russian side for the entire episode. Unsurprisingly, the Russian side was not willing to accept this, and another day was lost while the same document was signed again by all parties, this time without the Ukrainian declaration. Monitors were deployed on 11 and 12 January. $^{39}$

Any hopes that the deployment of monitors would allow gas flows to resume rapidly dissipated, and the period 13-17 January was spent in mutual recriminations. The Russian side again claimed that its attempts to flow gas were being blocked. The Ukrainian side repeated that no gas was being delivered, and also argued that no supplies could be received because of the lack of a technical agreement between the parties. ${ }^{40}$ The Ukrainian position was presented in a letter and accompanying draft agreements, sent by Naftogaz General Director Dubyna to Gazprom CEO Miller. Dubyna argued that Gazprom should not only provide technical gas, but also linepack gas of $140 \mathrm{mmcm}$ for the restart of deliveries. ${ }^{41}$ By this time, the situation, particularly in south-eastern Europe, was becoming desperate. At this point, we proposed from the Natural Gas Programme at the Oxford Institute for Energy Studies that, given the failure of monitors to resolve the crisis, the EU itself should offer to provide finance for linepack and technical gas, in order to get supplies moving to alleviate the humanitarian crisis in the Balkans. ${ }^{42}$

A significant detail about the second phase of this dispute is that, once the Ukrainian transport system was closed to deliveries of Russian gas, Naftogaz Ukrainy reversed the flow

\footnotetext{
${ }^{38}$ This is a complicated document which sets out a range of tasks for the monitors in addition to verifying flows. 'Terms of reference for the monitoring of the transit of natural gas through Ukraine', www.gazprom.com/eng/news/2009/01/33576.shtml

39 'Chto podpisala Timoshenko s Rossiei i Evrokomissiei', Ukrainska Pravda, 13 January 2009 (where the declaration is reproduced in full). In a press release issued 11 January, the Commission tried to finesse this by saying 'nothing in the Ukrainian Declaration adds to, or subtracts from, the Terms of Reference signed by the parties', IP/09/34, Brussels, 11 January 2009; 'EU bid to revive Russia gas deal’, BBC News, 12 January 2009; Christian Lowe and Dmitry Zhdannikov, 'Russia-Ukraine deal on gas for Europe in doubt', Reuters, 11 January 2009

${ }^{40}$ In this context 'technical agreement' refers to the requirement for both sides to agree - Gazprom to propose and Naftogaz to accept - daily 'nominations' i.e. volumes of gas to be delivered. In the absence of Ukrainian willingness to accept and confirm nominations, it would not have been possible for Gazprom to deliver gas because of the potential dangers arising from the network not being able to receive it

${ }^{41}$ Letter from Dubyna to Miller and 'Vremennoe tekhnicheskoe soglashenie' published on Naftogaz Ukrainy website, 14 January 2009

${ }^{42}$ Stern, Jonathan, (2009), Resumption of Russian gas deliveries to central and east European countries on humanitarian grounds: a proposal, (OIES, January 2009).
} 
in the system, in order to transport gas from Ukraine's storage facilities, which are mostly in the west of the country, to major consuming areas in the south and east. This reversal of one of the world's largest gas transit systems was unprecedented. It seems hard to believe that it could have been undertaken spontaneously, which suggests that, whichever side precipitated the shutdown, Naftogaz's engineers had prepared for it. Indeed, on 12 January, Gazprom announced that it was prepared to start delivering gas through the Sudzha metering station into the pipeline that traverses Ukraine towards south-eastern Europe, but Ukraine refused to accept this offer. Deputy CEO Medvedev claimed that the Ukrainian side had reconfigured the network to flow gas from the storage facilities in the west to supply consumers in the east, using the European transit pipelines in such a way as they were unable to accept Russian gas for transit to Europe. ${ }^{43}$ The Ukrainian position subsequently varied between claims that Russia had cut off supplies, and that no supplies could be received because of the lack of a technical agreement between the parties, which could not be concluded in the absence of a supply and a transit contract. Medvedev's claim confirms that Gazprom knew that the Ukrainian system was at this point working in reverse, and that Naftogaz could not accept gas through only one pipeline corridor without returning the flow to an east-west direction, making it impossible to supply large population centres in eastern Ukraine in particular. ${ }^{44}$ Not surprisingly, Naftogaz rejected this proposal and called for deliveries to be restarted simultaneously through all pipeline corridors. ${ }^{45}$

European gas companies, who in general did not comment on the dispute in its early stages, were by this time placing increasing pressure on Gazprom for a resolution. On 15 January, Prime Minister Putin proposed an 'innovative' solution in consultation with Paolo Scaroni, CEO of ENI of Italy: a consortium of European utilities would provide a temporary financial solution to the crisis by paying for the necessary linepack and technical gas in order to restart

\footnotetext{
${ }^{43}$ Interview with Alexander Medvedev on Ekho Moskvi, 12 January 2009; This was confirmed by Prime Minister Timoshenko in discussion with the European Commission and Eurogas, Interfax, 30 December 200814 January 2009, p.4.

${ }^{44}$ Work by Aleksandar Kovacevic suggests that Ukraine could either have resumed transit through a single pipeline (or eventually swap gas from storage), or shifted the entire network back into normal supply and transit mode. The intermediate solution that was attempted, with the monitoring mechanism requiring Ukraine to resume full scale transit to Europe without taking gas for its own use, was simply unrealistic taking into account the structure and geography of Ukrainian gas consumption.

45 'Naftogaz vriatuvav Odesu i Donets'k, ne pustivshi gaz na Balkani', Ekonomicha Pravda, 13 January 2009; 'NNJSC "Naftogaz of Ukraine" requires immediately to resume regular gas supplies via all the transit corridors', press release on Naftogaz website, 13 January 2009; 'Prem’er-ministry Bolgarii, Slovakii i Moldavii lichno ubedilis', chto Ukraina blokiruet tranzit gaza v Evropu', Gazprom press release 14 January 2009; Paxton, Robin et al, 'Ukraine draws on gas reserves in prolonged row', Reuters, 13 January 2009. See also interview with Aleksander Medvedev on Ekho Moskvy, 12 January 2009; Prime Minister Timoshenko in discussion with the European Commission and Eurogas, Interfax, 30 December 2008-14 January 2009, p.4.
} 
flows, while negotiations on contracts continued. ${ }^{46}$ But in the event, no such arrangement was needed as the two sides finally negotiated two new contracts covering supply and transit which were signed on 19 January. Gas flows to Europe restarted on the morning of 20 January and two days later were returning to normal levels.

46 'Innovative solution to allow gas transit to resume', Ukrainefacts, 15 January 2009. This mentions a volume of $1.7 \mathrm{bcm}$ needed for linepack and technical gas, much higher than other accounts. 


\section{The resolution of the Commercial Dispute: the 10 year supply and transit contracts}

On 19 January, Prime Ministers Putin and Timoshenko signed an agreement to end the dispute, and the heads of Gazprom and Naftogaz signed supply and a transit contract, both covering the ten year period 2009-19. On the $22^{\text {nd }}$ leaked copies of the contracts were published on the Ukrainska Pravda internet news site. ${ }^{47}$ The contracts are complex documents, and only the most important provisions are included here, as follows: ${ }^{48}$

-- The supply contract (Article 2) provides for $40 \mathrm{bcm}$ of gas to be delivered to Ukraine in 2009 and 52 bcm annually (the annual contract quantity) from 2010 to the end of the contract period. Volumes are stated for each three monthly period for 2009-10. ${ }^{49}$ Unless the parties agree, the volume in any one year cannot exceed 120 per cent of the annual contract quantity, and there is an 80 per cent take or pay provision.

-- Prices will be 80 per cent of a 'European price' in 2009 and 100 per cent from 2010 (Article 4). For the first quarter of 2009 , the price will be $\$ 360 / \mathrm{mcm}$ based on a 'European price' (Po) of $\$ 450 / \mathrm{mcm}$ minus 20 per cent. It appears that this Po is a price 'netted back' from a European (possibly German) border, which would mean that it is based on a European price of around $\$ 495 / \mathrm{mcm}$. The price will change quarterly according to the average of 50 per cent gasoil/50 per cent fuel oil prices over the previous three quarters with no 'lag'. The formula has a number of technical specifications (prices to be taken from Platts Oilgram monthly European averages, fuel oil is 1 per cent sulphur, etc.).

-- There are strict rules on taking extra gas, and strict payment terms, for Naftogaz Ukrainy.

There are price consequences of taking more gas than agreed in the contract; this will be charged at 150 per cent of the contract price in the months April-September and 300 per cent during October-March (Article 4.3). The price clause can be renegotiated in the event that either side believes it no longer reflects market conditions (Article 4.4). Naftogaz Ukrainy is required to pay monthly for 100 per cent of gas delivered by the $7^{\text {th }}$ day of the

\footnotetext{
${ }^{47}$ Ukraine Russia Supply Contract and Ukraine-Russia Transit Contract. Note that the copies of the contracts supplied to the newspaper missed a few words or lines off the bottom of some pages.

${ }^{48}$ However they are considerably shorter and less complex than their European counterparts.

${ }^{49}$ Article 2.1 states that the gas may be supplied from Russia, Kazakhstan, Uzbekistan, and Turkmenistan.
} 
month following the delivery month (Article 5). However, should the buyer fail to make that payment by the due date, at any time during the contract, then it will be required to pay for the following month's gas in advance, by the last day of the preceding month, for the remainder of the contract (Article 5.8).

-- Sales will be made directly by Gazprom to Naftogaz Ukrainy on Ukraine's borders with Russia and Belarus (Article 2). This means that RUE will no longer ship or supply gas to Ukraine.

-- Gazprom's wholly-owned Ukrainian trading subsidiary, Gazprom-Sbyt, will market at least 25 per cent of the imported gas, i.e. $10 \mathrm{bcm}$ in 2009 and $13 \mathrm{bcm} / \mathrm{year}$ from 2010 (Article 9.7). These sales are to be made to industrial customers, who pay substantially higher prices, and are better payers, than those in the residential and district heating sectors. Under agreements concluded in March 2008, Gazprom-Sbyt bought gas from Naftogaz and its mark-up was limited to $\$ 0.01 / \mathrm{mcm}$. Whether this provision will continue is not specified.

The main points of the transit contract are:

-- The annual transit volume for the ten year period will be not less than $110 \mathrm{bcm}$, and in 2009 the volume will be $120.083 \mathrm{bcm}$ (Article 3). ${ }^{50}$ Quarterly volumes to be delivered in 2009 to Moldova and Europe by each individual transit pipeline are specified.

--The transit tariff will be $\$ 1.7 / \mathrm{mcm} / 00 \mathrm{~km}$ in 2009 although the revenue which Ukraine will receive should take into account an advance payment of $\$ 250 \mathrm{~m}$ which Gazprom made under an amendment to the previous transit contract. ${ }^{51}$ From 2010, the tariff will be $\$ 2.04 / \mathrm{mcm} / 00 \mathrm{~km}$ plus an element based on 2009 prices which, if they average $\$ 250 / \mathrm{mcm}$ will add \$0.6 to the tariff. From 2011, the tariff will comprise 50\% of $\$ 2.04$ plus 50\% of the previous year's tariff indexed to European Union inflation rates (Article 8).

\footnotetext{
${ }^{50}$ The fact that Gazprom appears to have taken on a commitment to transit at least $110 \mathrm{bcm} / \mathrm{year}$ through Ukraine for the duration of the contract is very strange given the clear imperative to build Nord and South Stream which would greatly reduce deliveries through Ukraine below such levels. This can perhaps be explained by other wording in the contract allowing renegotiation of terms if conditions change.

${ }^{51}$ See Dopolnenie 4 of the June 2002 contract dated August 4, 2004. For details of the 2002 contract see section on major points of dispute below.
} 
-- Gazprom will make an advance payment for transit services of $\$ 1.7$ billion, under an annex to the contract. ${ }^{52}$ This money must be used to pay 'legal claims on RUE transferred in favour of Naftogaz by Gazprom [or its affiliates]'. The nature of these claims is not stated, but detailed reports of leaked Ukrainian government correspondence, which appear to corroborate statements made by Prime Minister Timoshenko, suggest that these claims may be settled with the transfer to Naftogaz of $10.5 \mathrm{bcm}$ of gas that belonged to RUE and was being stored in Ukraine. If the transaction is closed in the manner reported, Naftogaz will acquire this gas at around $\$ 153 / \mathrm{mcm}$. The transaction may also cover linepack and technical (fuel) gas used by Ukraine during the first week of the dispute, and make redundant the agreement between the six European gas companies and Gazprom on that issue referred to above. ${ }^{53}$

Both contracts include provision for international arbitration in Stockholm.

From this brief summary of the main points of the contracts, several issues immediately arise:

- The first of these is that Naftogaz Ukrainy will face a tremendous struggle to make the monthly payments required by Articles 4 and 5 of the supply contract. Payment for imported gas has been a problem for Ukraine throughout the entire post-Soviet period, and it would be surprising if this were to change in future, particularly given higher prices. Article 4.6 of the supply contract states that the value of all volumes imported to Ukraine in 2009 is $\$ 14.4$ billion, but this assumes a price of $\$ 360 / \mathrm{mcm}$ for the entire volume (see notes to Table 1 ), and the price paid will be much lower. Nevertheless, it will be a burden on Ukraine. This needs to be considered in the context of:

(a) the substantial deterioration in Ukraine's terms of trade and its current account position, due to the coincidence of falling international prices for steel, its main export, the increase of the price of imported gas, and the general effects of the economic crisis;

\footnotetext{
${ }^{52}$ Russia-Ukraine Transit Contract, Dopolnenie 1.

53 'Gazovy direktivy. Zaradi znishchennia Firtasha Timoshenko porushila zakon?’, Ukrainska Pravda, 21 January 2009. See also report of Timoshenko press conference, Interfax, 15-21 January 2009, p. 6.
} 
(b) the serious fiscal crisis that moved the IMF to make its $\$ 16.5$ billion loan to Ukraine, and the falling value of the hryvna (from 5:1 to 7.7:1 against the dollar over the last four months); and

(c) the Ukrainian political crisis, which may affect the level and character of state support for Naftogaz.

The means available to Naftogaz to pay for imported gas are (a) revenues from Ukrainian customers (in broad terms, at the tariffs set in January, these would be in the best case - i.e. assuming that demand is sustained, which is questionable during the recession - about \$7.7-7.9 billion for sales of $30 \mathrm{bcm}$ to industrial customers, and \$900-950 million for sales of $10 \mathrm{bcm}$ to district heating companies),

(b) some of its transit revenue income (expected to be $\$ 2.35$ billion, minus the $\$ 1.7$ billion advance payment), and in any case sufficient transit revenue to cover the cost of $7 \mathrm{bcm}$ of technical gas, and

(c) government subsidies. Again this emphasizes the extent to which Naftogaz's ability to pay will depend on the type of support it receives from government.

- Furthermore, despite all the claims by both sides about the likely level of gas prices in 2009 and beyond, these will completely depend on oil prices. Speculation that prices will average between $\$ 190-250 /$ mcm for 2009 is mainly aimed at vindicating the claim of one side or the other that they had 'won' the negotiation on prices. It will not be possible to give a price for 2009 until the end of the year, when we shall know the level of oil prices (on which gas prices will be based). An alternative method of calculating the 2009 price will be to take the different quarterly gas import volumes at the different quarterly prices and derive a single average figure for the year. ${ }^{54}$

In these circumstances, there must be a concern that payments will again become an issue of dispute between the companies which could once again escalate - as in this crisis - to the point of disconnection, with consequent impacts on European supplies.

\footnotetext{
${ }^{54}$ Article 2.2.1 of the supply contract gives the following volumes: Q1 $-5 \mathrm{bcm}, \mathrm{Q} 2-10.5 \mathrm{bcm}, \mathrm{Q} 3-12 \mathrm{bcm}$, $\mathrm{Q} 4-12.5 \mathrm{bcm}$. This means that Ukraine will be purchasing the least gas at the higher price of $\$ 360 / \mathrm{mcm}$ in the first quarter, and most of its volumes in the second half of the year when it is anticipated (but not certain) that prices will be lower.
} 
However, these two contracts definitively change the methodology of Ukrainian gas pricing. While the prices charged to Ukraine by Gazprom/RUE during 2006-8 had been 'netted forward' from Central Asia, i.e. based on Central Asian purchase prices, plus transportation charges plus the RUE profit margin, the prices in the new 2009 contracts are intended to be European netback market prices, based on and indexed to oil products. Thus from now on, prices of, and transportation charges for, Central Asian gas, are no longer relevant for Ukraine. This is an advantage for Ukraine because it removes the risk of having to accept prices agreed between Gazprom and Central Asian countries over which it has no control. In the event, those parties appear to have agreed a price for exported central Asian gas of around $\$ 300 / \mathrm{mcm}$ for 2009 , which would have resulted in a price for Ukraine similar those under the European formula for the first quarter of the year. ${ }^{55}$

Only a few weeks after these contracts have been signed it is hard to speculate on their future. President Yushchenko, while promising to 'abide by' the contracts, has said that Ukraine has made a 'bad deal', which is 'not based on partnership'. Within a week of the conclusion of the dispute, Yushchenko's staff reviewed the agreements with a view to renegotiating them, and the presidential website published a lengthy legal commentary, suggesting that Ukraine could renegotiate the agreements because they are 'discriminatory'. All this suggests that, in addition to Ukraine's difficulty in paying for imported gas, the political divisions about the agreements in Kiev could mean that further disputes will arise. ${ }^{56}$

\footnotetext{
${ }^{55}$ And possibly throughout the year if the Central Asian price formulae also have quarterly adjustments with oil product indexation.

56 'President makes comment on gas deal with Russia', website of Ukrainian presidency 20 January 2009; 'Gas dispute should not be considered economic or financial’, ibid., 28 January 2009; 'Gazovye soglasheniia dolzhny vypolniat'sia, odnako ikh osnovatel'nyi analiz tozhe neobkhodim - Igor’ Pukshin', ibid., 28 January 2009;' Tony Barber, 'Yushchenko pledges to honour “bad” gas deal’, Financial Times, 28 January 2009
} 


\section{The Position of Gazprom and the Russian Government}

It is often asked whether there are any differences between the view of Gazprom and the Russian government. Since the latter has a controlling interest in the company and, directly or indirectly, appoints and/or approves all major personnel appointments, some believe that Gazprom operates as an economic and political arm of the government. This crisis showed Gazprom and the government working together, with the company taking its strategic direction from Prime Minister Putin, presumably with the tacit agreement of President Medvedev who only sporadically issued statements. ${ }^{57}$ Thus while President Putin was in charge of Russian decision making during the January 2006 crisis, Prime Minister Putin was clearly in charge in January 2009.

Gazprom's performance in the 2009 crisis compared well with its lamentable performance during the January 2006 crisis, where little was said publicly, and its (relatively coherent) commercial case for a higher price was drowned out by accusations that it was using energy as a political weapon against Ukraine’s Orange Revolution and its president, who Moscow had desperately tried to prevent coming to power. The company handled the 2009 crisis much more professionally. In mid December 2008, as debts were mounting and warnings were being issued about the likelihood that supplies would be cut off, with potentially adverse consequences for European supplies, a Gazprom delegation headed by Alexander Medvedev (no relation to the president), one of the company's Deputy CEOs and head of Gazprom Export, toured European capitals - including Brussels. He explained the situation and warned of potential problems. ${ }^{58}$ On December 29, as it was becoming clear that deliveries to Ukraine would probably be affected, Gazprom opened a website for the crisis - Ukrainefacts - which carried daily reports of meetings, press conferences, and the company's version of events as they unfolded.

A number of themes emerged. First, while Gazprom completely refuted any suggestion that it was using gas as a political weapon, from the beginning of the crisis the company repeatedly accused the Ukrainian president of ultimate responsibility for the crisis. According to

\footnotetext{
${ }^{57}$ See for example: Conversation between president Medvedev and Gazprom CEO, http://english.pravda.ru/russia/kremlin/106927-gazprommedvedev-0

${ }^{58}$ Ukrainefacts 6 January: After the events of 2006-07 we established an early warning system with our partners, customers, and European customers and have been keeping them informed.
} 
Gazprom, on 31 December, when the majority of the debt had been cleared, Prime Minister Timoshenko and Naftogaz CEO Dubyna had accepted an agreement which included a price of $\$ 250 / \mathrm{mcm}$ and a transit tariff of $\$ 1.7 / \mathrm{mcm} / 00 \mathrm{~km}$, but Timoshenko was prevented from flying to Moscow to sign the deal by the president. (This was denied by Yushchenko). ${ }^{59}$ Thus one of Gazprom's strongest arguments was that the basic problem lay in a power struggle for the future presidency between Yushchenko and Timoshenko, whose aim was to use the dispute to score domestic political points with the Ukrainian electorate. As a result, Naftogaz Ukrainy, which has no independent access to foreign currency without the approval of its president and prime minister, had no mandate to negotiate. On 1 January, Gazprom press secretary Kuprianov said: 'The main problem was not that we disagreed on the price of gas but that the Naftogaz delegation did not have a mandate to sign a new contract'. This was targeted specifically at the Ukrainian president by Alexander Medvedev on 6 January at a press conference: 'The Ukrainian delegation left the negotiating table six hours before the deadline. We understand that Mrs Timoshenko had accepted the proposed terms but this was blocked by Mr Yushchenko'. ${ }^{60}$

On 3 January, Gazprom announced that it had taken the decision to file proceedings against Naftogaz Ukrainy at the International Arbitration Court in Stockholm with reference to breaches of the June 2002 transit contract guaranteeing unimpeded transit of European gas across Ukraine for the period 2003-13. ${ }^{61}$ It was also reported that RUE had made two similar filings with the Stockholm Court, one relating to transit and the other to volumes of gas in storage, to which the company has allegedly been unable to obtain access. ${ }^{62}$ The status of this transit contract is a key legal issue in the dispute, and Gazprom published a legal opinion it had commissioned which, unsurprisingly, concluded that the contract remained valid and in effect. $^{63}$

On 13 January, Gazprom informed all its European customers that it had declared force majeure on all of its European gas contracts. This is an extremely unusual instrument to be invoked in European gas contracts and is usually relevant only in the case of accident or

\footnotetext{
${ }^{59}$ Interfax, 30 December 2008-14 January 2009, p.10.

60 'Gazprom Deputy Chief Executive Alexander Medvedev spoke to journalists in London', Ukrainefacts, 6 January 2009.

${ }^{61}$ Ukrainefacts, 3 January 2009.

62 “"Rosukrenergo AG” podalo iski v Stokgolmskii arbitrazh na Naftogaz, kotoryi ne vydaet treideru gaz iz khranilishch', 3 January 2009, www.interfax.ru

${ }^{63}$ For details of the transit contract see the section on 'major points of dispute' below, Ukrainefacts 5 January, opinion from the law firm DLA Piper
} 
technical failure. While we have no claim to legal expertise, we question whether force majeure is applicable in a situation in which the contractual relationship between two parties in a transit contract has prevented the terms of a supply contract from being fulfilled.

Even if Russia's most serious allegation against Ukraine, that it shut down the pipeline system on the night of 6-7 January, were proven, Russia clearly played its part in widening the scope, and therefore prolonging, the dispute. The Russian offer, prior to the end of the year, of export prices for 2009 of $\$ 250 / \mathrm{mcm}$ (in our view slightly high, but a realistic negotiating position), was then replaced (as the Russian side had previously warned) by the unrealistic price range of $\$ 400-450 / \mathrm{mcm}$; which seemed a triumph of exasperation over logic. On 6 January, in response to Ukraine’s use of Russian gas for technical purposes, Gazprom (by its own account) reduced the flow of gas into the pipeline system to $65 \mathrm{mmcm}$ for that day, less than half of what was needed, even had Ukraine replaced what it had taken. By turning the issue of technical gas into one of principle, and describing this gas as 'stolen', Russia helped to escalate the dispute in a way which eventually led to the disruption of supplies to Europe. ${ }^{64}$

Given that the alleged theft of $65.3 \mathrm{mmcm}$ (or even $115.3 \mathrm{mmcm}$ if we add in the additional $50 \mathrm{mmcm}$ ) is a relatively small volume of gas over a period of four days, given a daily transit volume of $250-300 \mathrm{mmcm}$, the crucial question is why the Russian side was prepared to take this risk. At stake were direct European sales losses of around $\$ 100 \mathrm{~m} /$ day plus penalties for failing to deliver under these contracts, plus possible damages claims. ${ }^{65}$ These losses could only be recouped in the event that litigation for damages in the Stockholm court would be successful, but in the best case this would be some years hence. Moreover, it should have been immediately clear that Russia's reputation as a reliable supplier of gas, built up over 40 years, would be irrevocably damaged. In addition, given the parlous state of the Ukrainian economy, it was not realistic to expect that the country would be able to pay a very substantially higher price for gas in 2009. Having made those - not very difficult -

\footnotetext{
${ }^{64}$ Even on 13 January, when Gazprom attempted to resume supply, it chose to do so via the Sudzha entry point towards the Orlovka exit point in order to highlight the inability to transit gas through this route which certainly did not help to resolve the impasse. 'Resumption of transit gas flow through Ukraine', Ukrainefacts, 13 January 2009.

${ }^{65}$ In the immediate aftermath of the crisis, a number of countries - specifically Bulgaria and Greece mentioned losses of \$333m and Euros 1bn for which they might seek damages. Interfax, 22-8 January 2009, p.14; 'Bulgaria to claim damages from Gazprom and Wintershall over stoppage', Gas Matters Today, 23 January 2009. The Hungarian prime minister suggested the EU should take action on behalf of member states to recover damages, 'Russia-Ukraine deal reopens the pipes', International Gas Report, February 2, 2009, pp. 3-5.
} 
calculations, the Russian side, despite its conviction that it was legally and contractually in the right, could have stepped back and, albeit with a loss of political 'face', accepted a lower price from Ukraine for its gas. Russia's actions indicate that, for its government - and specifically for Prime Minister Putin - pursuing its dispute with, and in some sense punishing, Ukraine, was a higher priority than ensuring that gas supplies to European customers were maintained, which was in Gazprom's long term (and probably even short term) commercial interest. Such a conclusion inevitably leads to further political speculation as to whether Putin's decision was aimed at further destabilising an already unstable Ukrainian economy and political system, and particularly the Ukrainian president for his proEU and NATO policies and support for Georgia in the August 2008 conflict, although it is not clear what he could have hoped to gain from such action, even had it been successful.

This in turn raises the general question of the relationship between political and economic factors in Russian and CIS gas trade. The authors of this paper have been among those who have insisted that economic factors played a greater role than is assumed in much of the commentary. With respect to the 2006 dispute between Russia and Ukraine, one of us wrote recently: ‘To portray Gazprom’s tough stance on prices as motivated by political revenge, or to depict its policy on pipeline infrastructure [i.e. seeking control of it] as simply a projection of Russian imperial ambitions, would be as naïve as to deny the role of politics altogether. [...] For Moscow, the price reform is an end in itself, as part of market reforms. Gazprom's drive to take control of pipeline infrastructure [...] has primarily an economic motivation, i.e. Gazprom's concern with ensuring uninterrupted supply to its European customers, who remain its key source of sales income. ${ }^{66}$

These arguments stand up well with respect to the 2006 dispute. Since then, the most important changes have been economic. The sharp falls in oil prices in the last six months have brought Russia's oil boom to an end; the market capitalization of Gazprom and the Russian oil companies have fallen by 60-75 per cent; the credit crunch has combined with these factors to make it difficult for them to raise investment capital. ${ }^{67}$ The fall in European gas prices that will this year result from lower oil prices will impact heavily on Gazprom's export revenues. Under these conditions, it was to be expected that Gazprom would drive as

\footnotetext{
${ }^{66}$ Pirani (ed.), Russian and CIS Gas Markets, p. 445.

${ }^{67}$ Gazprom's market capitalization is estimated to have fallen by 75 per cent during 2008. Carola Hoyos,

'National oil groups' shares hit harder by downturn', Financial Times, 26 January 2009.
} 
hard as possible a bargain on Naftogaz's outstanding debts, and on 2009 prices and transit fees. What was unexpected, at least to us, was that the Russian government and Gazprom would play its part in allowing the dispute first to escalate to the point where supplies to Europe were completely cut off, and then to allow this situation to continue for two weeks. All previous transit crises - including 2006 - pale into insignificance in comparison with the January 2009 events.

The most convincing explanations of Russian actions are that from 1 January, once gas had been cut off:

(i) Russian government and Gazprom management set out intentionally to embroil Europe in the dispute with Ukraine, in the hope of joining with Europe to impose a new regime on the Ukrainian transport system. The transit issue, which has been a subject of dispute between Moscow and Kiev for years, has now become a matter of public discussion in the EU. The introduction of EU monitors could be the prelude to greater European gas company involvement; the consortium proposal (see the section on European gas companies below), which was never implemented, could have been another possible step in this direction. Moreover, in an interview with German television, Putin stressed that Russia still considers revival of the 2002 gas transit consortium, which began as a Russian-German-Ukrainian initiative, as a viable solution to the transit problem. ${ }^{68}$ This was a highly provocative suggestion and may have been a response to the December 2008 USA-Ukraine Charter on Strategic Partnership, which included proposals on joint rehabilitation and modernization of gas transit infrastructure, leading to Russia accusations that the USA bore some responsibility for the crisis. ${ }^{69}$ Putin's suggestion led to a predictably swift negative response from the Ukrainian president. ${ }^{70}$ The aftermath of the crisis has seen wellreasoned arguments in favour of a consortium including Gazprom, Naftogaz,

\footnotetext{
${ }^{68}$ Interview published on www.government.ru/, 15 January 2009

${ }^{69}$ United States-Ukraine Charter on Strategic Partnership, Section III(2), US Bureau of European and Asian Affairs, Washington DC, December 19, 2008. Pinchuk, Ellen and Bradley Cook, 'Putin blames Bush for Ukraine gas war; is “optimistic” on Obama’, Bloomberg, 26 January 2009.

${ }^{70}$ See, possibly in response to the Putin suggestion, the statement by President Yushchenko reaffirming this position: 'Ukraine will never agree to a change of ownership of its gas transit system', 14 January 2009, www.president.gov.ua/en/news/12605.html
} 
European energy companies, and international financial institutions, but such an option still faces many political obstacles, particularly in Ukraine. ${ }^{71}$

(ii) Prime Minister Putin and Gazprom management, exasperated with what they saw as Ukraine's ability to blackmail them with threats to reduce supplies to Europe, and, even without any particular goal in mind, decided that a prolonged reduction was worth risking in order to achieve a redefinition of transit relations. Russia has always sought a transfer of ownership of the pipeline system to Gazprom, but failing that, it hoped to enforce some other solution.

In either of these cases, once battle had been joined, it appears that voices less willing to compromise gained the upper hand.

\footnotetext{
${ }^{71}$ Gnedina, Elena, and Michael Emerson, The Case for a Gas Transit Consortium in Ukraine: a cost-benefit analysis, CEPS Policy Brief No. 180, January 2009.
} 


\section{The Ukrainian positions}

The presentation of Ukraine's position on the dispute has been marked by the lack of unity in the government and, specifically, the deep divisions between President Yushchenko and Prime Minister Timoshenko. On 31 December, the prime minister's office stated that she had been due to fly to Moscow to help Naftogaz officials resolve the dispute, but had cancelled her trip at the last minute; it was suggested that the president was in some way responsible. ${ }^{72}$ A political analyst close to the prime minister has argued that the president's office not only schemed to keep the prime minister out of the negotiations, for fear that she would resolve them successfully and take credit, but also encouraged Oleg Dubyna to send his letter, threatening to disrupt transit of Russian gas to Europe, in order to make resolution more difficult. ${ }^{73}$ Whether or not this particular version of events is true, it is clear that some in the Ukrainian government were more prepared to make compromises with Moscow than others, and as a result mixed messages were sent out.

Notwithstanding these differences, on 1 January 2009, the president and prime minister jointly presented Ukraine's proposals for resolving the dispute. They referred to the PutinYushchenko agreement of 12 February 2008, and the Putin-Timoshenko agreement of 2 October, as 'substantial steps' towards improved collaboration. They proposed import prices of $\$ 201 / \mathrm{mcm}$, and transit tariffs of $\$ 2 / \mathrm{mcm} / 100 \mathrm{~km}$, claiming that these conformed to the methodology in the Putin-Timoshenko memorandum. They called for Russia to ensure, jointly with Ukraine, that transit to Europe would be uninterrupted, and proposed that 'accounts for mutual obligations (including for technical gas see Box 2) should be corrected and mutually settled' once negotiations on 2009 prices were signed. ${ }^{74}$ Another consistent element in the Ukrainian position from 1 January was that, under conditions where Ukraine is transiting but not importing gas from Russia, and in the absence of either a new contract or an intergovernmental memorandum as required by the transit contract for 2003-13, technical gas needed to be provided by Russia. This was Naftogaz’s justification for taking $21 \mathrm{mmcm} / \mathrm{day}$

\footnotetext{
${ }^{72}$ Yushchenko (see footnote 59 above) suggests that she was already on her way and turned back.

${ }^{73}$ Ibid and Vasilii Stoiakin, 'Kto sorval gazovye peregovory?’, Ukrainska Pravda, 12 January 2009

74 'Zaiavleniie Ukrainy o postavkakh i tranzite rossiiskogo prirodnogo gaza', www.president.gov.ua, 1 January 2009
} 
of technical gas from volumes destined for Europe, and thus driving the dispute to a new level. It made this point formally to Gazprom in published correspondence. ${ }^{75}$

Naftogaz published on its website the decision of the Kiev arbitration court of 9 January 2009, upholding an application from the energy ministry that the transit contract for 2003-13 was null and void, because intergovernmental memoranda which, under the contract, should set out transit fees, had not been signed. While the joint statement from president and prime minister, and other statements by Naftogaz, have reiterated that Ukraine considers itself dutybound to transit gas, but have argued that it must be supplied with technical gas from Russia in order to do so, this decision implied that transit should be stopped altogether. The Ukrainian energy minister, Yuri Prodan, claimed that this decision effectively outlawed gas transit under the contract. While we cannot venture a legal opinion, we would assume that the parties to the contract, which was signed under international law with provision for arbitration at the Stockholm commercial court, would not be subject to the Kiev commercial court's decision; nor could that court's decision override Ukraine's duties as a signatory of the Energy Charter treaty to transit gas. ${ }^{76}$

Even if Ukraine's most serious allegation against Russia, that Gazprom unilaterally shut off gas supplies on the night of 6-7 January, were proven, Ukraine has clearly played a big part in provoking and prolonging the dispute. It had already shown in January 2006, and unequivocally threatened in March 2008, that it would respond to Russian cut-offs by diverting volumes bound for Europe. The threat to do so again, made in Dubyna's letter to Gazprom on 31 December (assuming it is genuine), could only have been calculated to obstruct a settlement. Ukraine made its final payment for gas received in 2008 (\$1.52 billion on 30 December) so late that there was little possibility either of resolving the issue of alleged fines and penalties, or of completing a negotiation on 2009 import prices, before Ukraine’s supply was cut off. Ukraine’s demand that Russia provide technical gas - a departure from the normal practice that the transit country provides it - further raised the stakes. As noted above, on 10 January, when signing the EU memorandum on the terms of reference for the monitoring agreement, Prime Minister Timoshenko attached a declaration to it that she can

\footnotetext{
${ }^{75}$ Letter from O. Dubyna to A. Miller, 14 January 2009, draft 'Soglashenie o merakh, obespechivaiushchikh tranzit rossiiskogo prirodnogo gaza cherez territoriiu Ukrainy', and draft 'Vremennoe tekhnicheskoe soglashenie', all published on Naftogaz Ukrainy website, 14 January 2009;.

${ }^{76}$ Economic Court of Kyiv, Decision in the name of Ukraine (case no. 5/5), 9 January 2009, published on Naftogaz Ukrainy website, 13 January 2009; facsimile pages of a leaked copy of the contract in question are at www.pravda.com.ua/news/2005/12/22/36935.htm
} 
not have expected Russia to accept, effectively torpedoing the efforts to restart transit pending a resolution of the Russo-Ukrainian dispute. A key weakness in the Ukrainian position on monitors is that, because Ukraine had already decided that it would not accept any transit gas without having signed a technical and a transit agreement, monitors would make no immediate difference to the resumption of gas supplies to Europe. Hence, at a minimum, participation in the monitoring agreement, without making that position clear to all parties, was an exercise in bad faith by the Ukrainian side which prolonged the dispute by at least some days. ${ }^{77}$

The most obvious risk that Ukraine has taken by prolonging the dispute is to its reputation in Europe as a transit country. One certain outcome of the dispute is that there will be an even greater determination from Gazprom - and perhaps also from European countries - to build the North Stream and South Stream transit avoidance pipelines, which will impact heavily on Ukraine's gas transit business. Some in the Ukrainian political elite may have thought the reputational damage to Russia would be greater than that to Ukraine - but they can not have confidently planned such an outcome. It is much more likely that, to the extent that there was any planning, the calculations were short term:

(i) because of sharply reduced industrial demand and warmer weather late last year Naftogaz had $16 \mathrm{bcm}$ of gas in storage, meaning that Ukraine could survive a gas cut-off for several weeks;

(ii) as oil prices fell sharply in the second half of 2008, European gas prices would fall sharply from March 2009 (since they are mostly indexed to 6-9 month averages of oil product prices with a three month delay).

Certainly, the falling oil prices prompted Ukrainian politicians from November to call for formulae with a more immediate link to oil prices, allowing for gas prices to fall sooner. This was a slight departure from traditional European price indexation, and from the approach taken by the Putin-Timoshenko memorandum. People might well have gambled on using gas in storage and waiting, as falling prices weakened Gazprom's bargaining position. ${ }^{78}$

\footnotetext{
${ }^{77}$ The monitoring agreement was negotiated during 7-10 January and finally signed on 11/12, but Dubyna's letter and draft agreements which Naftogaz required to be signed before transit would be allowed to restart, were not sent to Miller until 14 January, see note 75 above.

78 'U Ukrainy est' 16 mlrd. kub m. gaza', RBK-Ukraina, 22 December 2008; Alla Eremenko, 'Glavnoe, ne zatianut' do paskhi', Zerkalo Nedeli, 8 November 2008; Vasilii Kashin et al, 'Gazovaia intriga', Vedomosti 29 December 2008.
} 
Kiev's approach to the dispute must also be put in the context of Ukraine's most serious financial and economic crisis since independence. Ukraine's economy went into recession in the fourth quarter of 2008 and is expected to contract by 3-5 per cent in 2009. The year-onyear fall in industrial production to December was 26.6 per cent. The steel industry, which accounts for more than 40 per cent of Ukraine's export revenues, has contracted sharply, and steel producers cut production by up to 50 per cent in the second half of 2008. Ukraine's terms of trade have abruptly worsened, as international steel prices have fallen sharply, while gas import prices rise. Ukraine's financial system was more vulnerable to the credit crunch than any other in Europe, and the $\$ 16.5$ billion loan made by the IMF in October, the largest in the fund's history as a proportion of a country's share of the fund, reflected concerns about a possible collapse. ${ }^{79}$

This deep economic crisis seems to have made politicians more willing to prolong the dispute with Russia because:

(i) they gambled that industry could survive for longer with less gas, and

(ii) the need to postpone price increases became more desperate.

However, in the second week in January, there were clear signs that the dispute with Russia would impact on Ukrainian consumption much sooner. Although the amount in storage at the start of the dispute was equal to two months' supply, the technical difficulties of transporting it had led to industrial enterprises being cut off, for example from 9 January in the Odessa region. A combination of lack of gas availability and the uncertainty surrounding prices, also led Naftogaz, in agreement with the minister of industrial policy, to cut the supply of gas to chemical fertilizer producers by 75-85 per cent. These are the most gas-dependent enterprises, since they use gas as a raw material. The minister stated that whether production restarted would depend on gas prices since, if they are above \$200, most of the production would be loss-making. Naftogaz reported on 9 January that industrial consumption had fallen from $65-70 \mathrm{mmcm} /$ day in December to $45 \mathrm{mmcm} /$ day during the dispute. ${ }^{80}$

\footnotetext{
79 'Rost VVP v Ukraine v 2008 g. sostavil 2.1\%', RBK-Ukraina, 15 January 2008; Wagstyl, Stefan and Roman Olearchyk, 'Divided stand', Financial Times, 3 December 2008; World Bank, Ukraine Economic Update, December 2008; Fitch Ratings, Ukraine: Risks Mounting for External Finances, 29 September 2008.

${ }^{80}$ Polityuk, Pavel and Guy Faulconbridge, 'Gas row cuts Ukraine industry gas use by a third', Reuters, 9 January; ‘V Odesskoi obl. nachalos’ otkliuchenie’, RBK-Ukraina 9 January 2009; Paxton, Robin and Sabina Zawadzki, 'Ukraine draws on gas reserves in prolonged row', Reuters 13 January 2009; Chernovalov, Aleksandr, 'Gaz iskliuchili iz kursa khimii’, Kommersant, 14 January 2009.
} 


\section{The influence of business groups in the dispute}

On 14 January Ukrainian politicians accused each other of aggravating the dispute with Russia on behalf of business groups with interests in the gas sector. Prime Minister Timoshenko said that an agreement with Russia, based on import prices of $\$ 235 / \mathrm{mcm}$ and transit tariffs of $\$ 1.70-\$ 1.80 / \mathrm{mcm} / 100 \mathrm{~km}$ had nearly been achieved, but had broken down. She claimed that the blame lay with RUE's part owner, Dmitry Firtash, former energy minister Yuri Boiko, and former head of the presidential administration Sergei Levochkin, who had lobbied against it, and suggested that President Yushchenko had been complicit. The implication, presumably, was that Firtash and his friends had disrupted the deal in the hope of RUE retaining the shipping contract, which it stood to lose if the direct contracts envisaged in the Putin-Timoshenko October memorandum were put in place. Shortly afterwards Boiko responded that Timoshenko was herself lobbying in the interests of businesses owned by Igor Bakai, who played a major role in the Russo-Ukrainian gas trade in the 1990s, and Viktor Medvedchuk, a senior politician under former President Kuchma. Boiko claimed that Timoshenko had delayed payment of Ukraine's gas debts while attempting to arrange for a company owned by Medvedchuk and Bakai to export substantial volumes of Russian gas (4.5 bcm in the first quarter). ${ }^{81}$

It is difficult to comment on specific allegations, since business groups' influence on politicians in Ukraine is by its nature opaque. It may be that such lobbying contributed to Ukraine's slowness in negotiations. However, the idea that this lobbying was the main cause of the dispute, or the cause of it expanding into a crisis for gas transit to Europe, flies in the face of economic realities. There is no evidence that Gazprom would have tolerated a twoweek disruption of its sales to Europe, its most important source of revenue, from which it earns tens of billions of dollars a year, for the sake of changes to its relationship either with Firtash or with other players such as those mentioned in the Ukrainian parliament. We therefore dispute the interpretation of the gas conflict, offered in a comment contributed to the Financial Times, that while public attention focuses on the governments, 'the real fight

\footnotetext{
81 ‘Timoshenko obvinila Firtasha, Boiko i Iushenko’, Ukrainska Pravda, 14 January 2009; ‘Boiko: Timoshenko lobbirovala gazovyi biznes Bakaia i Medvedchuka’, Ukrainska Pravda, 14 January 2009
} 
over the share-out [of gas revenues] is taking place more discreetly between a few oligarchs in Moscow and Kiev. This is perhaps the whole purpose of the noisy puppet show. ${ }^{82}$

In the case of Firtash, who has profited most successfully in recent years from the RussoUkrainian gas trade, if the agreements of 19 January stand, his companies will lose their 45 per cent share of RUE's profits from the Turkmen-Ukrainian shipping contract. The future of other aspects of his business - in particular, RUE’s very profitable resale of central Asian gas in central Europe, as well as gas and electricity trading in central Europe - is not known. Firtash companies have been acquiring stakes in the Ukrainian gas distribution sector, and Firtash recently claimed that RUE controls 75 per cent of it ${ }^{83}$ - but, again, it simply defies logic that a dispute on the scale of January 2009 could be triggered for the sake of this. It should be borne in mind that:

(a) at present the Ukrainian gas distribution sector is inherently loss-making, and

(b) if Firtash's stake in it is exercised through RUE rather than other vehicles, then it is a shared venture with Gazprom.

The settlement of the crisis appears to leave Firtash at a major disadvantage. Gazprom has reportedly agreed on the transfer of RUE's stored gas to Naftogaz as part of the $\$ 1.7 \mathrm{bn}$ advance payment package, and Gazprom Deputy CEO Medvedev has claimed that: 'It is clear that after the signing of contracts, there will be no sources of gas for RUE in Russia, Central Asia, or Kazakhstan'. ${ }^{84}$ This may account for the problems that Poland has experienced due to RUE failing to deliver gas under its contract with PGNiG, as a result of which the Polish prime minister is seeking to negotiate directly with Gazprom, in addition to seeking alternative supplies. ${ }^{85}$ But even if Firtash knew that his central European business was in danger, we doubt that he or his business competitors had the economic and political clout to cause a dispute on this scale. They were very much a secondary element.

\footnotetext{
${ }^{82}$ Guillet, Jerome, and John Evans, 'The battle of the oligarchs behind the gas dispute', Financial Times, 6 January 2009.

${ }^{83}$ Reznik, Irina, 'RUE uzhe kontroliruet 75 per cent prodazh gaza na Ukraine', Vedomosti, 11 January 2009.

${ }^{84}$ Interfax, 22-8 January 2009, pp. 20-1. However it is not clear where this leaves RUE's long term contract with Gazprom.

85 'Polish flows dip to 76 per cent of normal', and 'Polish imports still down', Platts European Gas Daily, 27 January 2009, p.3 and 5 February 2009, p.2; 'Poland looking at alternative suppliers following gas dispute’, Interfax, 29 January-4 February 2009, pp. 13-14.
} 


\section{Major Points of Dispute between Russia and Ukraine: the 2002 transit contract}

We have set out what we understand to have been the basic points of contention between the parties during 6-19 January which were that:

- according to the Russian side, Ukraine was blocking the pipelines and

- $\quad$ according to the Ukrainian side, Russia failed to deliver gas.

We have covered the question of Russian allegations of gas theft and the Ukrainian response that they were entitled, in the absence of a transit contract, to take the 'technical gas' necessary to operate the transit network. We have also shown that the public Ukrainian position was that transit could not be restarted until (at least temporary) technical and transit agreements were signed by the parties, but in reality, resumption of transit required a resolution of the supply contract with Russia. Much of this pre-supposes that the existing transit contract between the parties was no longer valid. Such was the Ukrainian position, contested by Gazprom. Whether the 2002 transit contract remained valid post-2008 is therefore crucial. If it did not remain valid then Russia was in breach of its obligations to European customers. If it did remain valid then Ukraine was in breach of transit obligations by taking technical gas. ${ }^{86}$

The major message that the January 2009 gas crisis sent is that a transit contract - the cornerstone of any transit relationship - is not necessarily a guarantee of secure transit. Although we are not in a position to provide a legal opinion on the contractual position of Gazprom and Naftogaz in the run-up to the crisis (not least because the relevant contracts are not all in the public domain) our understanding is that the contract concluded between Gazprom and Naftogaz in 2002, on the basis of which Ukraine transited Russian gas to Europe, was not due to expire until 1 January $2014 .{ }^{87}$ Reportedly, according to this contract, the minimum annual volume of gas to be transited across Ukraine was $110 \mathrm{bcm}^{88}$ The Naftogaz letter to Gazprom claims that the contract envisages that transit volumes must be

\footnotetext{
${ }^{86}$ Either way, it seems to us that Ukraine was not entitled to take the $140 \mathrm{mmcm}$ of linepack which appears to have disappeared during the crisis.

${ }^{87}$ Kontrakt 'Ob ob”emakh i usloviakh tranzita rossiskogo gaza cherez territorii Ukrainy na period s 2003 po 2013 gody’, 21 June 2002, http://pravda.com.ua/news/2005/12/22/36934.htm (not available in full).

${ }^{88}$ Article 3.1, which reportedly stipulates this, is not available in public domain. See Naftogaz i Gazprom: perepiska on www.echo.msk.ru/blog/echomsk/563350-echo.phtml
} 
agreed on the basis of annual intergovernmental protocols and stated in annual addendums to the contract. ${ }^{89}$ Therefore citing the lack of agreement on many 'significant conditions' of the contract, such as transit volumes and transit fees in 2009, as well as the absence of annual technical agreement, Naftogaz claimed that it did not have legitimate reasons to accept Russian gas through customs. What seems crucial is that both parties referred to the 2002 contract as the existing basis of their transit relationship, having cited obligations and disagreements arising from this particular contract. This suggests that the transit contract remained applicable and, as subsequent events showed, did not prove to be a guarantee of security when transit was shut down with no gas flowing out of Ukraine for two weeks.

An addendum to the 2002 contract was signed on 20 April 2007, which stipulated transit conditions until the end of 2009 , including a transit rate of $\$ 1.6 / \mathrm{mcm} / 100 \mathrm{~km} .{ }^{90}$ The text of this addendum is not available, at least to us. Nonetheless, assuming this addendum was signed, it must have been concluded in accordance with the principles laid down by the January 2006 Russia-Ukraine Agreement, which fixed a transit tariff for both Gazprom and RUE at $\$ 1.60 / \mathrm{mcm}$ until 1 January 2011, but envisaged a possibility of re-negotiating it provided that all parties concerned agreed. ${ }^{91}$ In fact, the transit tariff was re-negotiated and increased to $\$ 1.70 / \mathrm{mcm} / 100 \mathrm{~km}$ in 2008 .

The fact that the 2006 January agreement remained valid is indirectly confirmed by the October 2008 Gazprom-Naftogaz agreement, which states that the January 2006 Agreement is to be annulled only after a new contract based on the October 2008 Agreement is signed. ${ }^{92}$ Thus whereas the 2006 January Agreement established new supply provisions (introducing RUE as the sole supplier to Ukraine), transit provisions continued to be governed by the June 2002 contract. This is because the latter includes an article 'Other Conditions' which stipulates that irrespective of annulment of any provision of the contract, the rest of the contract remains valid. ${ }^{93}$

\footnotetext{
${ }^{89}$ Ibid.

${ }^{90}$ A press conference by A. Medvedev and S. Kuprianov, www.vesti.ru, 31.12.2008 and Naftogaz i Gazprom: perepiska on www.echo.msk.ru/blog/echomsk/563350-echo.phtml

91 'Ob uregulirovanii otnoshenii v gazovoi sfere’, Soglashenie, 4.01.2006.

http://pravda.com.ua/news/2006/1/5/37345.htm. For a detailed analysis of the January 2006 agreement see Stern 2006.

92 'O printsipakh dolgosrochnogo sotrudnichestva v gazovoi sfere', Soglashenie October, 2008, http://www.zn.ua/img/st_img/2008/718/718-sogl.gif

${ }^{93}$ Kontrakt 'Ob ob”emakh i usloviakh transita...', op.cit.
} 
It is important to note that while Article 13.1 of the January 2009 transit contract says that the June 2002 contract ceased to apply on 1 January 2009, Article 14.1 says that it covers the relations between the parties taking place beginning from 1 January 2009. This suggests that although the international arbitration clause may no longer apply to Ukraine under the June 2002 contract, it would apply under the January 2009 contract, as the latter also envisages an international arbitration clause. Therefore it could be argued that if Ukraine does not pay whatever sum has been agreed - for fuel gas and linepack appropriated in January 2009, the case could be brought to Stockholm on the basis of the 2009 contract. 


\section{The role of the European Union, Energy Charter Secretariat, and Member States}

\section{The European Commission}

In contrast to the 2006 crisis, when European Commission officials were severely criticized for only returning from holiday in time to welcome the end of the crisis, this time Brussels was much better prepared. Nevertheless, during the first few days, before European supplies were affected, the Commission did not intervene, 'watched' developments and called repeatedly for a rapid conclusion to the dispute. On 5 January, an energy spokesman for the European Commission called the dispute 'a "purely commercial” conflict which should be resolved bilaterally’. ${ }^{94}$ The Czech presidency - for fairly obvious historical reasons - was not keen to make any attempt to mediate between the two sides. At the same time, it acknowledged its determination to continue to bear 'pressure' on both sides, to bring them to the negotiating table. ${ }^{95}$ On the $5^{\text {th }}$, a 'fact finding mission' was sent to Moscow and Kiev and the following day, EC President Jose Manuel Barroso spoke to both the Russian and Ukrainian prime ministers by phone and: ${ }^{96}$

urged them to restore full gas supplies to the EU immediately. [He] [...] made clear that it was unacceptable that the EU's gas supply security was taken hostage to negotiations between Russia and Ukraine. He warned that reputation as reliable partners [...] was at stake [and] insisted that Ukraine and Russia had to find a stable and long-term solution to guarantee reliable gas supplies to the EU...In a new series of telephone conversations [on 9-10 January] President Barroso and [energy] Commissioner Piebalgs got assurances from both sides that if an international monitoring mission was deployed to control the flows of gas would be fully restored.

\footnotetext{
${ }^{94}$ Bennhold, Katrin, 'EU tries to stay neutral as Russia reduces gas flow to Ukraine', International Herald Tribune, 5 January 2009

${ }_{95}$ www.interfax.ru, 5 January 2009.

96 'Statement from President Barroso and Commissioner Piebalgs on the agreement for the gas monitoring', Commission Press Release, IP/09/33, Brussels, 11 January 2009.
} 
On 7 January, German Chancellor Angel Merkel telephoned both prime ministers and reached agreement with them that 'experts from the European gas industry and the EU be sent quickly to determine on both sides of the Russia-Ukraine border..the cause of the transmission problems'. ${ }^{97}$ From that date onwards the Commission then focussed on getting the terms of reference for the monitoring agreement signed by all parties. On 9 January, the Gas Coordination Group met and discussed a variety of measures including: temporary increases in production, increasing storage withdrawal, fuel switching, and increased LNG imports. ${ }^{98}$ And on the $11^{\text {th }}$, the Monitoring Agreement was signed and monitors from the Commission, gas companies, and gas transmission operators began to deploy at the agreed entry and exit points of the network in Russia and Ukraine. ${ }^{99}$ On the $19^{\text {th }}$ (when, as it turned out, the crisis was nearly over) the Gas Coordination Group issued another press release in which it explained some of the impacts on different countries and the measures which had been taken. Interestingly the Group thanked Norway, Algeria, and Libya for providing '..a steady and even increasing supply of gas..in this time of crisis. ${ }^{, 100}$

\section{European gas and utility companies}

When it became clear on 13 January, that the monitoring mission would have nothing to monitor because gas was still not flowing, European gas and utility companies - which had up to this point contributed most of the monitors but done little else - began to play a more active role. Some of these companies, Gazprom's main European customers, began to suggest that the Russian company needed to make greater efforts towards a resolution.

\footnotetext{
${ }^{97}$ www.germany.info/Vertretung/usa/en/_PR/P_Wash/2009/01/07_NaturalGas__PR,archiveCtx=2028290.ht $\mathrm{ml}$

${ }^{98}$ Measures discussed at the Gas Coordination Group, MEMO/09/4, Brussels 9 January 2009. On the same day the Group had a meeting with Gazprom, Naftogaz, and the Ukrainian Administration to 'discuss the current crisis and reach a common understanding between experts of the main elements of the dispute...' ' 'Monitoring team starts work in Kiev and Gas Coordination Group urges Naftgaz and Gazprom to resume deliveries immediately’, IP/09/24, Brussels 9 January 2009. The Group was set up in the wake of the 2006 crisis, under provisions in the Security of Gas Supply Directive 2004/67. It is composed of representatives of member state governments, gas company representatives, and consumers. It meets four times a year to exchange information and develop and coordinate gas security measures.

${ }^{99}$ Statement from the President Barroso, op cit; It is also worth noting another press release the same day which makes reference to the Ukrainian declaration to which Moscow took great exception and which may or may not have delayed the implementation of the monitoring mission. IP/09/34, Brussels, 11 January 2009.

100 'Gas Coordination Group: Solidarity works and the EU's gas market adapts to challenges of gas crisis', IP/09/75, Brussels, 19 January 2009.
} 
Following Naftogaz's declaration to Gazprom that $140 \mathrm{mmcm}$ of linepack and $21 \mathrm{mmcm} /$ day of technical (fuel) gas would be needed before transit to Europe could be restarted, a group of companies set about creating a vehicle to provide the finance for such gas. The idea of a consortium to provide this finance was announced by Prime Minister Putin on 15 January at a meeting with Paolo Scaroni, CEO of ENI. ${ }^{101}$ In 36 hours, a consortium was created consisting of: ENI, Gdf/Suez, E.ON/Ruhrgas, RWE, Wingas, OMV, and Gazprom. Legal documentation was signed whereby the consortium would provide the finance for gas to restart and to operate the transit network until the two sides had reached a long term settlement, after which a mechanism in the agreement provided for repayment of funds to the companies involved. While the consortium agreement was not needed (having been overtaken by a resolution of the dispute) it seems likely that it helped to speed up the process by removing the final Ukrainian objection - that it was not prepared to pay for linepack and fuel gas to restart the transit network. The consortium was set up by gas companies, backed by national leaders - Prime Minister Silvio Berlusconi of Italy and Chancellor Angela Merkel of Germany, together with Prime Minister Putin are said to have been particularly influential - but there is no suggestion that the Commission played any role. ${ }^{102}$

On 20 January, the EC president issued a statement giving his interpretation of the Commission's contribution to the resolution of the crisis: ${ }^{103}$

We have worked night and day for three weeks to get to this point. I have spoken in considerable detail and with great regularity to [the Russian and Ukrainian presidents and prime ministers]. I have made it very clear throughout that we insisted on the immediate resumption of deliveries. [...]We set up a monitoring team [...] which was vital for confidence building. But when it was clear that this was not enough, the Commission then sponsored the agreement on the Terms of Reference for the monitoring mission. [...] And finally when it was clear that agreement on the whole contract was going to be necessary in order for gas transit to be resumed, [Energy Commissioner Piebalgs] and I pushed hard for direct, substantial talks between the parties at a high political level. This has now led directly to settlement of the dispute

\footnotetext{
101 'Innovative solution to allow gas transit to resume', Ukrainefacts, 15 January 2009

${ }^{102}$ We are not aware of any publicly available information about the consortium; this account is the result of personal contact with some of the companies involved.

103 'Statement of President Barroso on the resolution of the Ukraine-Russia gas dispute', SPEECH/09/12, Brussels, 20 January 2009.
} 
[...] But at the same time, it is difficult to welcome something that should not have happened in the first place. It was utterly unacceptable that European gas consumers were held hostage to this dispute between Russia and Ukraine.

But in contrast to this interpretation, it is difficult to escape the conclusion that the Commission, played a rather minor role in the settlement of the dispute. Having set up the monitoring mission - with the assistance of European utility companies which provided most of the monitors - and finding that this did not result in a resumption of gas flows, it was reduced to the role of urging both sides to cooperate. It was left to European gas companies (with the backing of national governments) to raise the finance needed to restart the network, which arguably gave the signal for the two sides to come together to thrash out a solution. The overall impression from the crisis was that in this situation, the Commission:

- had little technical capability and needs to rely on the industry for monitoring capability;

- had little political credibility or political leverage with either Ukraine or Russia;

- was unable or unwilling to provide the financial resources to resolve the crisis.

This calls into question the usefulness of documents such as the Commission's $2^{\text {nd }}$ Strategic Energy Review with its concept of solidarity between member states. This was a situation in which south east Europe and the Energy Community Treaty countries needed a tangible demonstration of the Commission's ability to assist in an energy security crisis, and could not have been greatly reassured by its performance. ${ }^{104}$

\section{The ECT, the Energy Charter Secretariat and the consequences for gas transit}

Prior to the crisis, the Secretary General of the Energy Charter Secretariat issued a press release on the impending dispute warning that, regardless of whether it was receiving gas for itself, Ukraine had to ensure transit was not interrupted. The treaty obliges signatories to 'secure established flows of Energy Materials and Products to, from or between the Areas of other contracting parties', and a core element of this principle is 'to prevent non-transit-

\footnotetext{
${ }^{104}$ Article 45 of the Energy Community Treaty envisages a mutual assistance mechanism, according to which the ministerial council meets upon the request of the affected party and decides on response to disruption. We do not know whether any affected party made a request and if not, why not.
} 
related issues from having a negative impact on transit volumes'. ${ }^{105}$ On 9 January, the Secretary General repeated the terms of Article 7.5; reminded the parties of the dispute resolution procedure, and offered the services of former president of the International Gas Union (and former CEO of the Dutch company Gasunie) George Verberg to lead conciliation efforts. ${ }^{106}$ On 14 January, the Secretary General repeated that Mr Verberg was willing to conciliate, and drew attention to the scale of gas losses being suffered as a result of the crisis. $^{107}$

Thus, despite the best efforts of the Charter Secretariat, the existence of the Energy Charter Treaty, ${ }^{108}$ and the fact that Ukraine has signed and ratified it, Ukraine nevertheless failed to interpret correctly its transit provisions on non-interruption and non-reduction of transit flows. Given that the Treaty is, in our view, an instrument of prevention rather than resolution of transit disputes, it is of secondary importance that Russia had signed but not ratified the Treaty, and hence could not invoke its transit dispute conciliation procedure against Ukraine. Indeed Russian ratification of the Treaty might not have changed the fact that Ukraine failed to fulfil its commitments, although it would have greatly strengthened the Russian position. Moreover, in view of Ukraine's disregard of its Treaty obligations, even if conciliation had been invoked, there is no guarantee that the resulting (supposedly legally binding) decisions would have been honoured. But, again, had the Russian Federation ratified the treaty, responsibility for the outcome would not have been in doubt.

This crisis provided the ECT with the potential to raise its profile and prove that it could serve as an important instrument to manage transit relationships; unfortunately that opportunity was missed. The task was not easy, however. During the first 11 days of the crisis, the absence of an independent monitoring mission on both sides of the Ukrainian pipeline system meant it was impossible to tell whether Ukraine was taking gas out of transit pipelines, or whether Russia was failing to deliver gas into the system. Therefore it was impossible to claim with any certainty which party was responsible for reducing and/or interrupting transit volumes, and hence violating ECT principles. Arguably the monitoring

\footnotetext{
${ }^{105}$ Article 7.5 of the Treaty; 'Secretary General Issues Statement on Russia-Ukraine Gas Dispute’, Energy Charter Secretariat press release, 23 December 2008.

106 'Statement of the Secretary General on the recent developments in the Russia-Ukraine gas dispute', Energy Charter Secretariat press release, 9 January 2009.

107 'Russia-Ukraine gas dispute: Secretary General appeals for conciliation efforts', Energy Charter Secretariat press release, 14 January 2009.

${ }^{108}$ To which Ukraine, Russia, European Communities and its Member States are all parties. Full list of ECT members can be found on its website www.encharter.org
} 
initiative, eventually put in place by the Commission (see above) could have come from the ECT Secretariat, which could have attempted to put it in place before the crisis, especially as both Russian and Ukrainian representatives were warning Europe of imminent difficulties, but this would have been an extremely difficult diplomatic task.

Following the crisis, when the monitoring group was in place, the ECT secretariat could have attempted (and could still attempt) to institutionalize this arrangement within the Treaty framework. Thus this group could acquire a semi-permanent status which would allow its presence at both borders - Russia/Ukraine and Ukraine/European countries - following a request or a warning from either party about any potential transit difficulties in the future. ${ }^{109}$ Even in the absence of independent verification of transit flows, there was an opportunity for the ECT secretariat to raise the Treaty's profile. Ukraine's own admissions - first on the taking of technical gas, and more conclusively its refusal to restart transit in the absence of a new agreement providing linepack and technical gas - were sufficient to conclude that the ECT had been violated. Had the Energy Charter Secretariat, or the European Commission, or any of the Member States (all of which have ratified the Treaty) stated publicly at any stage of the crisis that Ukraine was not acting in accordance with its obligations under the Treaty, it could have sent an important signal to Ukraine. ${ }^{110}$ At the same time, such a step could have sent Russia a signal that the key European players took extremely seriously a violation of the ECT by a ratified party, and that the Treaty could perform a valuable function in resolving transit crises. It could also have gone some way towards responding to the cynicism of both Gazprom and much of the Russian political establishment, which was already evident during the 2006 crisis, that European calls for Russian ratification are aimed at holding Russia - but no other parties - accountable to the terms of the Treaty. ${ }^{111}$

Given that the 2006 Russia-Ukraine gas crisis (and the less well-known but nonetheless important 2004 Russia-Belarus gas crisis) had already provided serious warnings about potential future transit problems, certain steps could have been taken within the ECT framework. First and foremost this refers to improving transparency in relation both to flows

\footnotetext{
${ }^{109}$ Shortly after the restart of deliveries, the Secretary General issued a document which contains similar suggestions. 'A Word from the Secretary General on the Energy Crisis of Early 2009', February 6, 2009, www.encharter.org/index.php?id=21\&id_article $=171 \& \mathrm{~L}=0$

${ }^{110}$ This follows the argument of Stevens that the consequences of violating an international agreement are much more serious than those resulting from abrogation of a bilateral agreement. P. Stevens, Cross border oil and gas pipelines: problems and prospects, ESMAP technical paper, UNDP/World Bank, Washington DC, 2003.

${ }^{111}$ See Mitrova, Pirani and Stern in Pirani 2009, pp. 394-440, for Gazprom's reaction to the Energy Charter Treaty after the 2006 crisis.
} 
and supply and transit contracts between Russia and Ukraine (and other CIS transit countries). ${ }^{112}$ The 2009 January crisis highlighted these problems.

In the immediate aftermath of the crisis, both Gazprom management and Prime Minister Putin began to talk about creating a new transit framework to replace the Energy Charter Treaty. In his January 2009 speech at the World Economic Forum in Davos, Prime Minister Putin said: ${ }^{113}$

Unfortunately, the existing Energy Charter has failed to become a working instrument able to regulate emerging problems. Even countries that have signed and ratified it turn a blind eye to it just when it should be implemented. I propose we start laying down a new international legal framework for energy security. Guaranteeing the transit of energy resources remains a challenge. There are several ways of tackling it, and all must be used. The first is to adopt generally recognized market principles of fixing tariffs on transit services. They can be recorded in international legal documents. The second is to develop and diversify the routes of energy transportation.

This is a predictably harsh judgement from the Russian side. One could take the view that, had Russia ratified the Charter Treaty, it would have been able to invoke its dispute resolution procedure, thereby placing the Ukrainian side at an immediate and considerable international legal disadvantage. The fact that none of the European companies used the Treaty only reflected the fact that they had supply contracts with Gazprom, not transit contracts (or indeed any contracts) with Ukraine. ${ }^{114}$ However, it did not excuse the general European silence on public identification of the Ukrainian failure to live up to its Treaty obligations.

The ECT has taken more than a decade to gain ratification by more than 50 countries. Whatever instrument Russia may now propose is likely to take at least as long to put in place, and may be resisted by those countries not predisposed to accept a Russian initiative. Whatever its faults, the ECT is the only existing international transit regime, and is likely to

\footnotetext{
${ }^{112}$ Stern 2006.

${ }^{113} \mathrm{http} / / /$ premier.gov.ru/eng/visits/world/95/1921.html

${ }^{114}$ However, arguably, contracting parties to the ECT could have invoked dispute resolution under Article 27 of the ECT. Also a party to the Energy Community Treaty directly affected by the disruption could have made a request for a Ministerial Council to meet in order to consider the necessary measures in response to the disruption (Article 45 of the Energy Community Treaty).
} 
remain so for many years. However, this does not mean that it cannot be adapted using the lessons from this dispute, and particularly the need for monitors at all entry and exit points on a transit network in the event of a crisis. But this crisis has serious consequences for all energy transit relationships, as it suggests an inherent instability which cannot be completely eliminated because of the difficulties of monitoring energy flows. The crisis may constitute a paradigm shift for the way in which energy, and specifically gas, transit relationships may be viewed in relation to verification of obligations, and a more difficult future both for transit projects and any regime which seeks to regulate them.

\section{The impact on European gas consumers}

This study, completed only a few weeks after the conclusion of the crisis, cannot attempt a detailed account of the impact on European countries. Without wishing to minimize the inconvenience caused elsewhere (notably in Slovakia), by far the most severe consequences were in south-east Europe, specifically: Moldova, Bulgaria, Romania, Serbia, BosniaHerzegovina, and Croatia, and we are publishing a companion note on these consequences along with this study. ${ }^{115}$ In the Balkans, there were significant humanitarian consequences, especially during the second week of the crisis.

\footnotetext{
${ }^{115}$ Aleksandar Kovacevic, The Impact of the Russia-Ukraine Gas Crisis in South Eastern Europe, OIES, forthcoming 2009.
} 
Table 4. The Position of European Countries Affected by Interruption of Russian Supply

\begin{tabular}{|c|c|c|c|c|}
\hline Country & Cut & Diversification & Gas storage & Alternative fuel \\
\hline Bulgaria & $100 \%$ & No diversification & $\begin{array}{l}\text { Gas storage for } 2-3 \\
\text { days, covering } 35 \% \\
\text { of gas demand }\end{array}$ & $\begin{array}{l}\text { Alternative fuel for } \\
20 \text { days }\end{array}$ \\
\hline Slovakia & $97 \%$ & No diversification & $\begin{array}{c}\text { Gas storage for } \\
\text { several weeks, } \\
\text { covering } 76 \% \text { of gas } \\
\text { demand }\end{array}$ & $\begin{array}{c}\text { Alternative fuel for } \\
\text { one month }\end{array}$ \\
\hline Greece & $80 \% \mathrm{BD}$ and $\mathrm{TR}$ & $\begin{array}{l}\text { Only LNG terminal, } \\
\text { fully capable, booked } \\
\text { more ships }\end{array}$ & $\begin{array}{c}\text { Only in LNG } \\
\text { terminal }\end{array}$ & $\begin{array}{l}\text { One gas power plant } \\
\text { switched to oil, } \\
\text { sufficient till end of } \\
\text { January }\end{array}$ \\
\hline Austria & $66 \%$ & $\begin{array}{c}\text { Increased import } \\
\text { from Norway and } \\
\text { Germany }\end{array}$ & $\begin{array}{l}\text { Gas in storage for } \\
\text { several weeks }\end{array}$ & Yes \\
\hline Czech Republic & $71 \%$ & $\begin{array}{c}\text { Increased import by } 8 \\
\text { mmcm/day from } \\
\text { Norway, and via } \\
\text { Yamal/Germany }\end{array}$ & $\begin{array}{l}\text { Gas from storage } 40 \\
\text { days, } 15 \% \text { increase of } \\
\text { domestic production }\end{array}$ & $\begin{array}{l}\text { Not used now, could } \\
\text { be coal and oil }\end{array}$ \\
\hline Slovenia & $50 \%$ & $\begin{array}{l}\text { Gas from Algeria via } \\
\text { Italy, and from } \\
\text { Austria but not } \\
\text { increased amount }\end{array}$ & $\begin{array}{l}\text { Gas from storage in } \\
\text { Austria till Monday } \\
\text { then possible } \\
\text { decrease of supply by } \\
\text { another } 20 \%\end{array}$ & Yes \\
\hline Hungary & $45 \%$ & $\begin{array}{c}\text { Increased gas from } \\
\text { Norway by } 5 \%\end{array}$ & $\begin{array}{c}\text { Gas storage for } 45 \\
\text { days }\end{array}$ & $\begin{array}{l}\text { Alternative fuel - } \\
\text { crude } 90 \text { days, fuel } \\
\text { oil } 30 \text { days }\end{array}$ \\
\hline Poland & $33 \%$ & $\begin{array}{c}\text { Half of the cut } \\
\text { covered by Yamal, } \\
\text { more gas from } \\
\text { Norway }\end{array}$ & $\begin{array}{l}\text { Gas storage for } \\
\text { several weeks }\end{array}$ & Yes \\
\hline Romania & $34 \%$ & No diversification & $\begin{array}{c}\text { Increased domestic } \\
\text { production (60\%) and } \\
\text { withdrawal from } \\
\text { storage }\end{array}$ & Yes \\
\hline
\end{tabular}




\begin{tabular}{|l|c|c|c|c|}
\hline Germany & $\begin{array}{c}60 \% \text { cut in Southern } \\
\text { Germany, 10\% total }\end{array}$ & $\begin{array}{c}+20 \text { mmcm receiving } \\
\text { from Yamal, more } \\
\text { from Norway and } \\
\text { Netherlands }\end{array}$ & $\begin{array}{c}\text { Gas storage for } \\
\text { several weeks }\end{array}$ & Not used now \\
\hline Italy & $25 \%$ & $\begin{array}{c}\text { Increased import } \\
\text { from Libya, Norway, } \\
\text { and Netherlands }\end{array}$ & $\begin{array}{c}79 \% \text { full, covers 50\% } \\
\text { of demand }\end{array}$ & Not used now \\
\hline France & $15 \%$ & Industry covered & $80 \%$ full & Not used now \\
\hline Serbia & $100 \%$ & $\begin{array}{c}12 \% \text { renegotiated } \\
\text { with HU }\end{array}$ & $\begin{array}{c}1 \text { mmcm, less than } \\
\text { one day, 8\% covered } \\
\text { by production }\end{array}$ & 3 weeks of fuel oil \\
\hline Bosnia & $40 \%$ & No diversification & No storage & $\begin{array}{c}\text { Fuel oil only for 20 } \\
\text { days }\end{array}$ \\
\hline FYROM & $100 \%$ & No diversification & No storage & $\begin{array}{c}\text { Fuel oil stocks need } \\
\text { only for industry }\end{array}$ \\
\hline Croatia & $40 \%$ & $\begin{array}{c}\text { Diversification to } \\
\text { Italy, but not used, } \\
\text { negotiations ongoing }\end{array}$ & $\begin{array}{c}\text { Increased domestic } \\
\text { production (43\%) and } \\
\text { storage withdrawal, } \\
500 \text { mmcm stored }\end{array}$ & Fuel oil for industry \\
\hline Moldova (observer) & $100 \%$ & No diversification & No storage & No alternative \\
\hline
\end{tabular}

Source: Gas Coordination Group, Member State General Situation According to Significance of Impact, Memo 09/3, Brussels, 9 January 2009.

Table 4 is from the EU Gas Coordination Group and sets out the immediately available gas and other fuel alternatives. North-west Europe was not much inconvenienced by the crisis, and none of the continent's major markets came close to cutting off - even interruptible customers, although reduced industrial demand resulting from deepening economic recession was a factor in this relatively comfortable position. Spot gas prices at the UK's national balancing point rose substantially for a few days and the interconnector pipeline switched to export mode on 6 January. ${ }^{116}$

\footnotetext{
${ }^{116}$ The impact of the crisis was slightly difficult to disentangle from other factors such as cold weather and the loss of a major Norwegian field during the same period. For details see International Gas Report, 19 January 2009, pp. 38-9.
} 
A number of countries had made investments since the 2006 crisis and were therefore in a much better position, but this did not apply to south-eastern Europe. The Gas Coordination Group emphasized that the industry did all it could to help those affected: ${ }^{117}$

- for Slovakia, the east-west flow was reversed and gas flowed from Germany through the Czech Republic. German gas companies also supplied additional gas to Hungary, Slovenia, Croatia, Serbia, and Bosnia-Herzegovina

- Hungary provided some of its strategic stocks to Serbia

- Domestic gas and LNG supplies were increased where possible.

Here was solidarity in action. However, it was perhaps fortunate that many of the 'old' member states had ample gas in storage that they would perhaps not need because the impact of economic recession meant that gas demand was at lower levels than would normally have been the case. ${ }^{118}$

\footnotetext{
${ }^{117}$ Gas Coordination Group: solidarity works and the EU's gas market adapts to challenges of gas crisis. IP09/75, Brussels, 19 January 2009.

${ }^{118}$ It has been suggested that this may have been rather profitable solidarity for European companies as they were selling gas out of their storages at high prices that they were fairly certain they would not need, and fairly certain they would be able to buy it back more cheaply - given falling gas prices - later in the year. Westphal, Kirsten, ‘Europe Held Hostage?’ Russian Analytical Digest, 53/09, pp. 15-18.
} 


\section{Consequences for Russia, Ukraine and Europe}

It is too early to suggest even the short, let alone the long, term consequences of this crisis for European gas and energy policies and balances. What we set out here is an outline of immediately available information, some early reactions of European stakeholders, and some of our own thoughts on likely long term consequences.

Gazprom's reputation for reliability of supply has been damaged, perhaps irreparably. This is not just because many were always predisposed, for ideological reasons, to believe that Gazprom was not a secure supplier, but because the majority of ordinary European citizens and politicians will not be interested in detailed legal/commercial arguments about which side was to blame for this crisis. From the point of view of the Czech foreign minister, 'The main lesson learned from this crisis is that Russia and Ukraine aren't reliable suppliers. Europe must think about alternative sources and pipelines. ${ }^{, 19}$ Others have expressed the completely understandable - view that their contracts are with Gazprom which, irrespective of the difficulties of managing its Ukrainian relationship, is legally obliged to deliver gas and failed to do so, resulting in loss and suffering, with no guarantee that events will not be repeated. Gazprom's credibility as a reliable supplier in the future will, to a considerable extent, rest on being able to demonstrate that it will not be dependent on its relationship with Ukraine as a transit route. In order to do this, it must either ensure that the Ukrainian network will henceforth be owned and operated by a European consortium involving Ukrainian, Russian, and EU companies, or it must press ahead as fast as possible with bypass pipelines. Both of these options are likely to require several years and billions of Euros to implement.

For Ukraine, in the short term, the agreements of 20 January highlight two problems:

(i) the difficulty that Ukraine will have - due to its broader economic and fiscal problems - in paying for gas imported at high prices, and

(ii) the political divisions in Kiev, which have resulted in the Ukrainian president raising the issue of renegotiating the agreements in the week after they were signed.

A further likely consequence of the dispute, as we have argued above, is that transit diversification projects to bring Russian gas to Europe without going through Ukraine will be accelerated. If it is accepted that, in the last resort, Ukraine's position as the dominant

${ }^{119}$ Interfax, 22-9 January 2009, p.5. 
transporter of Russian gas to Europe can be, and is, used as a powerful weapon in negotiations over prices, then transit diversification will mean that that weapon will be blunted or lost altogether. Furthermore, Ukraine will face a reduction of valuable transit revenue income.

These immediate and medium-term concerns often obscure a more obvious, but salient, issue: that Ukraine's dependence on imported Russian gas is, strictly in energy terms, a consequence of its very high gas demand. This in turn results from it having the most energyinefficient economy in the world. Gas is used in unusually large quantities: for example the heavily subsidized Ukrainian district heating system uses more gas than the entire Czech Republic. Ukrainian politicians constantly argue about the extent to which this or that clause in a contract, or a particular level of gas prices or transit tariffs, reflects the national interest but only rarely is the obvious point made that Ukraine's national interest would be best served by reducing dependence on imported gas, which would in turn reduce the relevance of arguments about prices, transit tariffs, and contracts. Ukraine can only really reduce its dependence on imported gas in two ways:

(i) by reducing consumption via energy-saving measures, and

(ii) by increasing its own gas production.

While Ukrainian governments in the 1990s were arguably too financially and economically weak to attempt such a long-term strategy, those of the 2000s have also failed to pay serious attention to these issues, despite the opportunity provided by a decade of economic growth. Now, with Ukraine moving back into recession, consideration of such a long-term outlook becomes simultaneously more urgent and more difficult.

European impacts need to be carefully classified into short, medium, and long term.

- In the short term, the next one to two years, the focus needs to be on central and particularly south-east Europe, in relation to additional interconnection with neighbouring countries, north-west Europe and southern European countries with the capacity to import additional LNG supplies from existing terminals, plus additional storage close to these markets. ${ }^{120}$

\footnotetext{
${ }^{120}$ A simple example is the lack of interconnection between Bulgaria and Turkey where lack of reverse flow capability meant that Bulgaria could not receive any gas from Turkey; this could be resolved relatively easily and cheaply.
} 
- In the medium term 2011-15, Ukraine bypass pipelines could resolve the security situation, but only if the problem is perceived to be Ukraine - or the Russia-Ukraine relationship. If the Nord Stream and South Stream had been in place on 1 January, the consequences of this dispute would barely have registered in the majority of European countries. ${ }^{121}$ But if, as some will believe, the problem lies not with Ukraine but with Russia, then the routes by which Russian gas reaches Europe are much less relevant. Towards the end of this period, new LNG receiving terminals could have been built (notably in Poland and Croatia where plans are well-advanced) but their sponsors need to pay attention to the likely state of global LNG supply and demand, as price competition with the established Pacific and Atlantic Basin LNG buyers could become an important factor.

- In the longer term, post-2015 and particularly post-2020, large scale Caspian and Middle East pipelines such as Nabucco are possible, and are now being intensively studied, in the immediate aftermath of the crisis. However, we do not believe that sufficient gas can be made available to fill a $30 \mathrm{bcm}$ pipeline from these countries to Europe before the late 2010 s at the very earliest. ${ }^{122}$

Finally, it needs to be remembered that European countries have long term contracts to import 180-200 bcm of gas from Gazprom, most of which stretch out to beyond 2025 and some beyond 2030. This crisis has not changed European obligations under these contracts. Moreover, as the current global economic crisis engulfs Europe, gas (and general energy) demand is falling rapidly and (in most countries) dramatically. In these uncertain times it will be difficult for companies to sign up new supplies merely for reasons of diversification and security of supply. Indeed, if their demand falls too far and too quickly, they may have problems meeting the take or pay obligations in their existing long term contracts.

\footnotetext{
${ }^{121}$ Mikhail Korchemkin has disputed this conclusion and shown that even with Nord and South Stream, Ukraine would still have had to transit $18 \mathrm{mmcm} /$ day to fully meet Russian demand in Europe. While we are happy to accept that conclusion, replacing (or doing without) $18 \mathrm{mmcm} /$ day seems to us a much easier task than replacing 250-350 mmcm/day. See Mikhail Korchemkin, Wall St Journal, 12 January 2009

${ }^{122}$ Pirani 2009, pp. 403-8.
} 


\section{Conclusions}

The 2009 Russia-Ukraine crisis was a landmark event in Russian gas relations with CIS countries and Europe; for Europe it was also a landmark gas and energy security event which will probably have far-reaching policy consequences. A crisis in Russia-Ukraine bilateral gas relations was not in itself a surprise. Many, including ourselves, had seen it coming as long ago as the summer of 2008. ${ }^{123}$ The surprise, indeed the shock, was that both sides allowed the dispute to escalate from disagreements about debts, prices, and transit tariffs to the point where supplies to Europe were completely cut off; and then allowed this situation to continue for two weeks in the middle of winter, with serious adverse humanitarian consequences for (especially) south-east European countries.

We do not believe that the often-cited desire of the Russian government to use energy as an economic or political 'weapon' against European countries played any part in this crisis. Russia's relationship with Europe in the gas sphere is and will remain one of mutual dependence: while Europe depends heavily on Russian gas supplies, Russia - which here means both Gazprom and the Russian state - relies heavily on the revenues generated from European sales.

By contrast, the critical Russian decision to cut back deliveries on 5 January was an unnecessarily risky and commercially irrational action at that stage of the dispute. That decision may have reflected Prime Minister Putin's anger and frustration, and been aimed at punishing Ukraine for its repeated threats to disrupt transit. These emotions may have been personalized to President Yushchenko, given the historical animosity of Russia towards the Orange Revolution and towards Yushchenko's subsequent policy orientation away from Russia. Another motive may have been to bring Europe into the intractable dispute over the Ukrainian transit network, with a view to changing future transit arrangements.

We do not believe that 'oligarchs' were a decisive influence on either the cause or the outcome of the crisis - despite the role alleged to have been played by RUE's part-owner

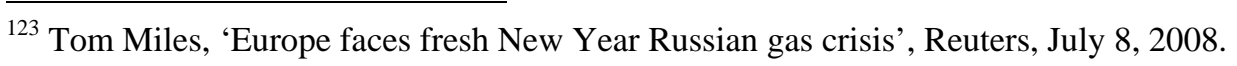


Dmitry Firtash - although they were probably a complicating factor and may have delayed its resolution.

Did either of the two sides bear more responsibility for gas supply being disrupted? From the evidence available to us, we conclude that, while there is room for debate on the facts and the legal basis of the actions of both sides, Gazprom's legal and contractual arguments appear to be much the strongest. However, we have been unable to make a forensic examination of the contractual documentation, or to have access to records of all of the gas flow data into and out of Ukraine during the crisis, which would be needed to confirm that conclusion. But we also believe that both responsibility for, and the longer term consequences of, this dispute go far beyond narrow judgements about legal and contractual responsibilities, which form only a part of the picture and not the most important part, except possibly for lawyers in any future arbitration proceedings. Irrespective of the origins of the dispute, once it had gone into its second phase, i.e. after Russian deliveries to Europe were stopped completely on 7 January, neither side demonstrated the required level of concern for the damage it was causing to both customers in, and long term relationships with, Europe. This crisis had no 'winners' only losers, and - with the exception of European energy utility companies and some European heads of state - none of the parties involved have emerged from it with any great credit.

Even if our conclusion on the legal and contractual arguments is accepted, the much bigger question is why both sides allowed this dispute to escalate to the point where 20 per cent of Europe's gas was cut off for two weeks in the middle of winter. ${ }^{124}$ In so doing, Gazprom lost around \$1.5bn of revenues due to lack of sales, plus whatever penalties its European customers may be due under their contracts and possible additional damages claims. Immeasurably more seriously, 40 years of Russia's reputation as a secure gas supplier, and Ukraine's reputation as a secure transit country, have been damaged, probably irreparably. The Russian government - almost certainly personalized to Prime Minister Putin - which took the decisions which eventually led, on 7 January, to the complete interruption of European supplies through the Ukrainian transit network, should have recognized these consequences and had the option of stepping back. In the short term, this would have

\footnotetext{
${ }^{124} 20$ per cent is the rough share of Europe's gas demand, on an annual basis, delivered via the Ukrainian corridor. However, the EU Gas Coordination Group refers to the European market having lost 30 per cent of its gas imports, which would be a slightly smaller share of total demand. 'Monitoring team starts work in Kiev and Gas Coordination Group urges Naftgaz and Gazprom to resume deliveries immediately’, IP/09/24, Brussels 9 January 2009.
} 
involved a loss of revenue (through conceding a lower price/higher transit tariff) and loss of political 'face' but could have avoided anything more profound. Russia decided to pursue the dispute nonetheless.

The Ukrainian position was characterized by desperation, engendered by Ukraine's serious economic crisis that rising gas prices will aggravate, and by divisions in the political leadership that were prioritized over any larger strategic aims. Ukrainian President Yushchenko and Prime Minister Timoshenko's divergent views on a variety of issues played an important part in causing the crisis. This division also played its part in prolonging the dispute for at least a week longer than necessary, when it became clear - following the deployment of EU monitors - that Ukraine had no intention of allowing supplies to Europe to resume in the absence of new bilateral supply and transit contracts.

This crisis demonstrates that the two sides lost control of their bilateral gas relationship, and that neither the European Union nor the Energy Charter Treaty was decisive in its resolution. In the final analysis, it was European energy and utility companies (prompted in part by their governments) - by providing both technical expertise through monitors, and offering financial resources for replacement linepack gas and technical (fuel) gas - creating the conditions for new contracts to be signed, which led to resumption of gas flows. Given the positions taken by both sides, it was impossible for Russian gas to continue to transit to Europe in the absence of a Russian supply contract with Ukraine. In such circumstances, even had Russia ratified the Energy Charter Treaty and its Transit Protocol, the outcome of the crisis in terms of gas flows might not have been different, although responsibilities would have been easier to identify. As such, there must be significant doubt that a key provision of the Charter Treaty - that in the event of a transit dispute, energy supplies must continue to flow pending dispute resolution - is, in the specific case of Russian-Ukrainian gas relations, workable in practice.

European, and particularly Central and East European, countries which suffered economic and humanitarian damage from this crisis, were principally concerned about the consequences of the failure to deliver gas for their economies and their citizens. As such, it does not matter very much to Europe which side was 'at fault' for this crisis. The issue for the future is that since Russian gas supplies through Ukraine have been cut off once, they could be cut off again. Thus the problem for both sides is one of credibility in relation to future 
supplies and transit. The problem for the Ukrainian side is that this crisis will have hardened Russian determination to greatly reduce its transit dependence by building the Nord Stream and South Stream pipelines; a development with serious financial consequences for a country in an already difficult economic situation. But for at least the next three - and probably the next five - years, the current level of European dependence on the Russia-Ukraine relationship will continue, and this is a serious concern given the strong likelihood of a further breakdown of commercial and political relations.

Specific consequences of this crisis cannot be foreseen less than three weeks after its (initial) resolution, and in any case are beyond the scope of this paper. However, some generalizations are possible. European companies have long term contracts for the import of Russian gas, most of which stretch 15-25 years into the future; there is no legal scope for significantly reducing volumes under these contracts. Whatever may be desired by European stakeholders, little can be achieved in terms of diversification away from Russian gas over the next few years. What could be achieved is a diversification of delivery routes away from Ukraine via Nord Stream and South Stream which, by 2015 (and perhaps earlier) could very substantially reduce the significance of Russia-Ukraine relations for European gas customers. Therefore if, as we suggest here, the central causes of this crisis were Ukrainian actions and the inability of both sides to manage their bilateral relationship, then these transit avoidance pipelines could be a large part of the solution. If, on the other hand, Russian actions - and particularly the political elements in Russian decision making - are judged to be the major problem, then the route(s) of the gas to Europe is irrelevant. From the actions of various stakeholders during the dispute, it appears that European political leaderships are much more likely than energy companies to place the emphasis on diversifying away from Russian gas supplies.

Over the next 10-20 years, European companies and governments will have options in relation to decisions from where their additional gas supplies should be sourced; and options to reorient energy balances away from gas towards other sources of energy, particularly for power generation. It is certainly possible that choices will include non-gas alternatives, and non-Russian gas supplies reaching Europe via non-Russian routes. The extent and speed with which such alternatives may be realized in the 2020s will tell us how much damage this crisis has caused in Europe to the image of gas in general, and to Russian gas in particular. 


\section{BIBLIOGRAPHY}

Gazprom website: www.gazprom.com

Global Witness, 'It’s a Gas - Funny Business in Turkmen-Ukraine Gas Trade’, April 2006. Available at:

www.globalwitness.org/media_library_detail.php/479/en/its_a_gas._funny_business_in_the_t urkmen_ukraine_g

Interfax: Interfax Russian and CIS Oil and Gas Weekly, various issues.

Naftogaz Ukrainy website. Available at: www.naftogaz.com/

Pirani, Simon, (2007), 'Ukraine’s Gas Sector’, Oxford: OIES. Available at: www.oxfordenergy.org/pdfs/NG21.pdf

Pirani, Simon, (ed.), (2009), Russian and CIS Gas Markets and Their Impact on Europe (OIES, Oxford University Press, Forthcoming February 2009).

Stern, Jonathan, (2005), The Future of Russian Gas and Gazprom (OIES, Oxford University Press: 2005)

Stern, Jonathan, (2006), The Russian-Ukrainian Gas Crisis of 2006 (Oxford, OIES, January 2006). Available at: www.oxfordenergy.org/pdfs/comment_0106.pdf

Stern, Jonathan, (2009), Resumption of Russian gas deliveries to central and east European countries on humanitarian grounds: a proposal, January 2009, Oxford: OIES. Available at: www.oxfordenergy.org/pdfs/comment_0109-1.pdf

Ukrainefacts website. Available at: www.gazpromukrainefacts.com

Ukraine-Russia Supply Contract: Kontrakt ot 19 ianvaria 2009 g. mezhdu Otkrytym Aktsionernym Obshchestvom “Gazprom”, Moskva, Rossiiskaia Federatsiia, i Natsional’noi 
Aktsionernoi Kompaniei “Naftogaz Ukrainy”, Kiev, Ukraina, o kupli-prodazhi prirodnogo gaza v 2009-2019 godakh. Published at www2.pravda.com.ua/ru/news/2009/1/22/87168.htm

Ukraine-Russia Transit Contract: Kontrakt mezhdu Natsional’noi Aktsionernoi Kompaniei “Naftogaz Ukrainy” Kiev, Ukraina, i Otkrytym Aktsionernym Obshchestvom “Gazprom”, Moskva, Rossiiskaia Federatsiia, ob ob”emakh i usloviiakh transita prirodnogo gaza cherez territoriiu Ukrainy na period s 2009 po 2019 godi.” Published at www2.pravda.com.ua/ru/news/2009/1/22/87178.htm.

An English translation is published at www.kyivpost.com/business/34679 and www.kyivpost.com/business/34682

Yafimava, Katja and Jonathan Stern, (2007), The 2007 Russia-Belarus Gas Agreement, Oxford Energy Comment, (OIES, January 2007). Available at: www.oxfordenergy.org/pdfs/comment_0107-3.pdf

Yafimava, Katja, (2007), Post-Soviet Russian-Belarussian Relationships: the role of gas transit pipelines, Ibidem-Verlag: Stuttgart. 


\section{UNITS OF MEASUREMENT}

The abbreviations used for units of measurement in this study are:

bcm: billion (thousand million) cubic metres

mmcm: million cubic metres

mcm: thousand cubic metres 